\title{
Faretta and the Personal Defense: The Role of a Represented Defendant in Trial Tactics
}

\author{
Richard H. Chused ${ }^{\dagger}$
}

In Faretta v. California the Supreme Court held that criminal defendants have a constitutional right to conduct their own defense. The author focuses on its sixth amendment analysis and argues that, in addition, Faretta impels trial courts to permit defendants to control the tactical course of their trials even when represented by counsel. He also proposes a framework for implementing a right to mixed representation.

In Faretta v. California the Supreme Court held that defendants who knowingly and intelligently waive their right to counsel before trial inust, as a inatter of constitutional right, be permitted to proceed pro se. ${ }^{1} \quad$ Faretta raises tantalizing questions about the degree of control that a defendant represented by counsel may exercise over his own defense. This Article discusses the judicial treatment of defendants who have attempted to influence the strategic choices of their counsel and suggests that the Faretta decision requires both Bench and Bar to accept significantly more intervention by active, represented defendants than has occurred in the past.

Traditionally, neither the judiciary nor the organized Bar has demonstrated much sympathy for represented defendants who actively seek to participate in the presentation of their own defense. ${ }^{2}$ Such

$\dagger$ Associate Professor of Law, Georgetown University Law Center. A.B. 1965, Brown University; J.D. 1968, University of Chicago Law School.

1. 422 U.S. 806, 835-36 (1975). See also Comment, Faretta v. California and the Pro Se Defense: The Constitutional Right of Self Representation, 25 AM. U.L. REv. 897 (1976); Note, The Constitutional Right of Self-Representation: Faretta and the "Assistance of Counsel," 3 Pepperdne L. Rev. 336 (1976).

2. Tensions arise in cases with both assigned and retained counsel. Compare Duke v. United States, 255 F.2d 721, 724-27 (9th Cir.), cert. denied, 357 U.S. 920 (1958), with United States v. Bridgeman, S23 F.2d 1099, 1118-19 (D.C. Cir. 1975), cert. denied, 425 U.S. 961 (1976). The courts have generally treated counsel-client problems similarly whether counsel is appointed or retained. But cf. Fitzgerald v. Estelle, 505 F.2d 1334 (5th Cir. 1974) (suggesting that somewhat less strict standards be applied for evaluating the competence of retained than appointed counsel). The obvious exception is assignment of counsel itself, not a problem when the defendant privately retains an attorney. The analysis in this Article, unless otherwise indicated, applies to both assigned and retained counsel. 
"active" defendants are denied the ability to replace counsel, kept in the dark about the right to proceed pro se, denied control over most important aspects of their trials, and, if indigent, assigned counsel without consultation. ${ }^{3}$ The dramatic growth in reported cases involving serious disagreements between attorneys and their client-defendants ${ }^{4}$ indicates the need for a thorough review of the accused's role in the

3. For the most interesting of numerous cases holding that a defendant may not select his assigned counsel, see Bedrosian v. Mintz, 518 F.2d 396 (2d Cir. 1975); Peters v. Gray, 494 F.2d 327 (7th Cir. 1974). Commentators have urged that indigent defendants deserve a more decisive role both in selecting appointed counsel and in imsuring that they are compensated. Tague, An Indigent's Right to the Attorney of His Choice, 27 Stan. L. Rev. 73 (1974); Note, Indigent Criminal Defendant's Constitutional Right to Compensated Counsel, 52 CORNELL L.Q. 433 (1967).

A detailed report of the operation of the Criminal Justice Act of 1964, 18 U.S.C. $\S 3006 \mathrm{~A}$ (1970), in the federal courts and, in particular, of the various district court plans under the Act for appoimting counsel may be found in SUBCOMMTTTEE ON CONstitutional Rights of tHe Senate Comm. ON the Judiciary, 90TH Congress, 2D Sess., The Criminal Justice Act In the Federal District Courts, 69-115 (Comm. Print 1969). Regardless of the method of selection used under the Act, defendants' choices are not given any effect in the assignment systems. See, e.g., United States v. Davis, 365 F.2d 251 (6th Cir. 1966). The Act provides below-market-rate payment for counsel appointed to represent defendants in the federal courts. See 18 U.S.C. $\$$ 3006A(d)(1)-(2). For a review of counsel appointment systems prior to 1965, see L. SilverstenN, DEFENSE of THE POOR 15-17 (1965); for a more modern look see LaFrance, Criminal Defense Systems for the Poor, 50 Notre Dame LAw. 41 (1974).

In some places administration of the right to counsel has become primarily nonjudicial. For example, in the District of Columbia Superior Courts counsel is assigned administratively while the defendant is waiting to be arraigned. No provision is routinely made for a defendant who wishes to talk about the role of counsel with a judge before counsel is accepted. Such a system provides less room for "active" defendants desiring to control the tactics of their cases than do systems where counsel is assigned in open court.

4. See, e.g., Stepp v. Estelle, 524 F.2d 447 (5th Cir. 1975); United States v. Bridgeman, 523 F.2d 1099 (D.C. Cir. 1975), cert. denied, 425 U.S. 961 (1976); United States v. Young, 482 F.2d 993 (5th Cir. 1973); United States v. Rosenthal, 470 F.2d 837 (2d Cir. 1972); United States v. Calabro, 467 F.2d 973 (2d Cir. 1972); United States v. Morrissey, 461 F.2d 666 (2d Cir. 1972); Lauchli v. United States, 432 F.2d 1207 (7th Cir. 1970); Brown v. Craven, 424 F.2d 1166 (9th Cir. 1970); Jackson v. United States, 412 F.2d 149 (D.C. Cir. 1969); United States v. Jones, 369 F.2d 217 (7th Cir. 1966); Umited States v. Poe, 352 F.2d 639 (D.C. Cir. 1965); Vess v. Peyton, 352 F.2d 325 (4th Cir. 1965); United States v. Terranova, 309 F.2d 365 (2d Cir. 1962); Duke v. United States, 255 F.2d 721 (9th Cir.), cert. denied, 357 U.S. 920 (1958); Swope v. McDonald, 173 F.2d 852 (9th Cir. 1949); United States v. Gutterman, 147 F.2d 540 (2d Cir. 1945); United States ex rel. Torry v. Rockfeller, 361 F. Supp. 422 (W.D.N.Y. 1973); Spears v. United States, 250 F. Supp. 698 (S.D.W. Va. 1966); State v. Gilbert, 105 Ariz. 475, 467 P.2d 63 (1970); People v. Williams, 2 Cal. 3d 894, 471 P.2d 1008, 88 Cal. Rptr. 208 (1970); People v. Hill, 70 Cal. 2d 678, 452 P.2d 329, 76 Cal. Rptr. 225 (1969); Pcople v. Gay, 37 Cal. App. 2d 246, 99 P.2d 371 (2d Dist. 1940); State v. Banks, 216 Kan. 390, 532 P.2d 1058 (1975); Shelton v. State, 3 Md. App. 394, 239 A.2d 610 (1968); People v. Wilson, 43 Mich. App. 459, 204 N.W.2d 269 (1972); State v. Townes, 522 S.W.2d 22 (Mo. Ct. App. 1974); State v. Sinclair, 49 N.J. 525, 231 A.2d 565 (1967); Walker v. Commonwealth, 214 Va. 258, 199 S.E.2d 518 (1973); Green v. Commonwealth, 211 Va. 727, 180 S.E.2d 531 (1971). 
presentation of his defense. ${ }^{.}$Although a criminal trial is typically described as a three-party relationship between court, defense, and prosecution, ${ }^{6}$ it is often more realistic to picture it as a four-corner contest between court, prosecution, defense counsel, and defendant.

The Article proceeds in four parts. Part I analyzes the listorical roots of the traditional doctrines surrounding the attorney-client relationship and concludes that the severe restriction these rules impose on the ability of a represented defendant to influence trial strategy liave been inappropriately developed from habeas corpus and riglit-to-counsel jurisprudence. Part II analyzes the opinion im Faretta v. California and argues that the decision requires acceptance of participation by represented defendants in their trials. Part III describes cases in which defendants have been permitted to present their defenses both in person and with the aid of counsel and finds that such cases provide a sound foundation for implementing Faretta. Part IV suggests some solutions for the practical problems arising from the right of defendants to proceed in person and witl counsel in the same trial.

Mere TACTICS AND THE CONSTitution:

Historical RoOTS FOR THE DOMINANCE OF COUNSEL

The traditional doctrine that decisions on nuatters of trial tactics are properly made by counsel alone finds support in three bodies of

5. In the narrow context of plea bargaining Professor Alschuler has noted:

Professor Jerome H. Skolnick has observed that, in the attorney-client relationship, the attorney usually regards himself as the "player." The material in this article has, of course, tended to support this conelusion. Most defense attorneys agree that a client must finally decide for himself whether to enter a plea of guilty, but they often adhere to this proposition in only a narrow and technical sense. Their view is not that a client may direct his lawyer to defend him at trial; it is merely that the client is free to seek a new lawyer when he is dissatisfied with the choice of plea that his attorney has advised.

Alschuler, The Defense Attorney's Role in Plea Bargaining, 84 Yale L.J. 1179, 130607 (1975) (citing Skolnick, Social Control in the Adversary System, 11 J. Conflict REsolution 52,65 (1967)). Thus, even in areas where the client is said to control the law suit, there is substantial doubt that the daily reality accords with theory. See also J. Casper, American Criminal Justice: The Defendant's Perspective (1972). For discussion of the lawyer-client relationship in civil cases, see D. ROSENTHAL, LAWYeR AND Client: Who's In Charge (1974).

6. E.g., aba Standards Relatino to the Administration of Cruminal JusTICE, The Defense Function $\$ 1.1$ (a) (1971) [hereinafter cited as The Defense FUNCTION]:

Counsel for the accused is an essential component of the administration of criminal justice. A court properly constituted to hear a criminal case must be viewed as a tripartite entity consisting of the judge (and jury, where appropriate), counsel for the prosecution, and counsel for the accused.

7. Id. $\$ 5.2(\mathrm{~b})$ states the traditional rule:

The decisions on what witnesses to call, whether and how to conduct crossexamination, what jurors to accept or strike, what trial motions should be made, 
precedent: habeas corpus bypass litigation, ineffective assistance of counsel disputes, and counsel assignment cases. ${ }^{8}$ A major focal point for the litigation of control questions arose from Fay v. Noia ${ }^{9}$ and Henry v. Mississippi ${ }^{10}$ in which the Supreme Court held that federal habeas corpus petitioners who have dehiberately bypassed a state procedural remedy for the presentation of a federal constitutional claim forego their right to seek redress in a federal forum. ${ }^{11}$ Inquiries into "deliberate bypass" have often resulted in decisions permitting counsel to bind a chient in tactical decisions to waive a constitutional claim. Ineffective assistance of counsel cases have consistently held that tactical matters are for counsel alone to resolve. Their rationale is that appraisal of counsel's performance would become impossible for the judiciary if every aspect of a trial were subject to the second-guessing of an appellate tribunal. Sinilarly, defendants have been denied the ability to control trial tactics by firing their attorneys, whether assigned or retained; courts routinely prohibit voluntary withdrawal of counsel or assignment of new counsel when the only reason for the change is a dispute over trial tactics. ${ }^{12}$ This section analyzes this triad of cases and concludes that their extension to prohibit represented defendants from participating in any tactical aspects of their trials is unfortunate, illogi$\mathrm{cal}$, and, after Faretta, unconstitutional.

\section{A. Deliberate Bypass Cases}

In Fay petitioner Noia allowed the time for filing of a direct appeal from his state conviction to lapse. He later filed a habeas petition in

and all other strategic and tactical decisions are the exclusive province of the lawyer after consultation with his client.

8. See Grano, The Right to Counsel: Collateral Issues Affecting Due Process, 54 Mins. L. Rev. 1175, 1252-63 (1970); Waltz, Inadequacy of Trial Defense Representation as a Ground for Post-Conviction Relief in Criminal Cases, 59 Nw. L. Rev. 289 (1964); White, Federal Habeas Corpus: The Impact of the Failure to Assert a Constitutional Claim at Trial, 58 VA. L. REV. 67, 69-76 (1972) [hereinafter cited as White]; Comment, Criminal Waiver: The Requirements of Personal Participation, Competence and Legitimate State Interest, 54 CALIF. L. REv. 1262 (1966) [hereinafter cited as Comment, Calif. L. Rev.]; Comment, State Criminal Procedure and Federal Habeas Corpus, 80 HaRv. L. Rev. 422 (1966) [hereinafter cited as Comment, Harv. L. Rev.]; Comment, Federal Habeas Corpus and the Doctrine of Waiver Through the Deliberate Bypass of State Procedures, 31 LA. L. Rev. 601 (1971) [hereinafter cited as Comment, La. L. Rev].

9. 372 U.S. 391 (1963).

10. 379 U.S. 443 (1965).

11. See White, supra note 8; Lay, Problems of Federal Habeas Corpus Involving State Prisoners, 45 F.R.D. 45 (1969); Comment, Calif. L. Rev., supra note 8; Comment, Harv. L. Rev., supra note 8; Comment, La. L. Rev., supra note 8.

12. United States v. Main, 443 F.2d 900 (9th Cir. 1971); United States v. Grow, 394 F.2d 182 (4th Cir. 1968); United States v. DeFreitas, 410 F. Supp. 241 (D.N.J. 1976). 
federal court seeking relief because he was convicted on the basis of a coerced confession. The Supreme Court held that the failure to appeal in the state courts did not deprive the federal courts of the power to grant relief in habeas corpus, but added that a "federal habeas judge may in his discretion deny relief to an applicant who has deliberately bypassed the orderly procedure of the state courts and in so doing has forfeited his state court remedies."18 The Court emphasized that the deliberate bypass decision unust be " 'an intentional relinquishment or abandonment of a known right or privilege" ${ }^{14}$ by the defendant and that "[a] choice made by counsel not participated in by the petitioner does not automatically bar relief." 15

This cryptic statement was discussed in slightly greater detail in Henry v. Mississippi, ${ }^{16}$ decided only 2 years later. Henry took certiorari to the Supreine Court from a state conviction for disturbing the peace. The conviction had been affirmed by the state supreme court despite the use at trial of evidence seized in violation of the fourth amendment, because counsel had failed to comply with the contemporaneous objection rule. ${ }^{17}$ The Supreme Court impled that an adequate state procedural ground for decision would not automatically bar a federal court from hearing a federal constitutional claim, but that access to a federal forum could be barred if the state procedural remedy were deliberately bypassed. ${ }^{18}$ The Court remanded for a factual hearing on the bypass question, noting that "trial strategy adopted by counsel without prior consultation with an accused will not, where the circumstances are exceptional, preclude the accused from asserting constitutional claims." ${ }^{19}$ Although Henry was heard on certiorari, succeeding courts have assumed that the case applies as well to the ability of federal courts to review state court decisions on collateral attack. ${ }^{20}$

The exceptional circuinstances phraseology of Henry has spawned an interesting yet confusing body of case law. Some courts have concentrated on the Henry language and have consequently permitted counsel to waive a client's access to a federal forum in all but excep-

13. 372 U.S. at 438.

14. Id. at 439 (quoting Johnson v. Zerbst, 304 U.S. 458,464 (1938)).

15. 372 U.S. at 439.

16. 379 U.S. 443 (1965).

17. The rule required that objection to the introduction of evidence be made at the time of its introduction. Counsel's objections were stated during argument on a motion for a directed verdict made at the conclusion of the government's case in chief, rather than at the point when the evidence was introduced. Id. at 445-46.

18. Id. at 450 .

19. Id. at 451 .

20. E.g., Nelson v. California, 346 F.2d 73 (9th Cir. 1965). Henry's reliance on Fay supports this use. 379 U.S. at 450. 
tional circumstances; ${ }^{21}$ others, looking to the $F a y$ language requiring participation by the accused in the waiver decision, have granted habeas petitions when the defendant was unaware of counsel's actions. ${ }^{22}$

The Supreme Court has not satisfactorily resolved this split in authority. The only clear exception to the ability of counsel to waive access to a federal forum is the decision to enter a plea of guilty. ${ }^{23}$

21. For example, in Nelson v. California, 346 F.2d 73 (9th Cir. 1965), a state prisoner alleged that unconstitutionally seized evidence had been used in his trial. His attorney had failed to pursue state suppression remedies, apparently because he felt that the search that produced the evidence was consensual. The court, without reaching the merits of the search question, held that a deliberate bypass of a state procedural remedy had occurred. Counsel's decision to forego a suppression motion, even if made without the knowledge of the defendant or over the objections of the defendant, bound the accused. The court, noting that a contrary ruling would "seriously impair the constitutonal guaranty of the right to counsel," found that only counsel was competent to make the decision whether to file a suppression motion. Id. at 81 . The Ninth Circuit has consistently followed Nelson. E.g., U.S. v. Palmateer, 469 F.2d 273 (9th Cir. 1972); Poole v. Fitzharris, 396 F.2d 544 (9th Cir. 1968); Davis v. Dunbar, 394 F.2d 754 (9th Cir. 1968). Cf. Curry v. Wilson, 405 F.2d 110 (9th Cir. 1968) (in a review on the merits, counsel's waiver held binding). Only when an attorney has demonstrated apparent incompetence by not knowing of the availability of a remedy, has the Ninth Circuit shown much willingness to permit a federal collateral attack after counsel chose a state court strategy. See Pineda v. Craven, 424 F.2d 369 (9th Cir. 1970).

Today the fourth amendment issues raised by Nelson would be moot. The Supreme Court's recent holding that fourth amendment questions are generally not cognizable in federal courts if a state provides a fair opportunity to raise the issue would have obviated the nced to consider the bypass question. Stone v. Powell, $96 \mathrm{~S}$. Ct. 3037 (1976).

Although other circuits have also held that decisions by counsel may operate as a bypass for purposes of collateral attack, they do not use the broad language of the Ninth Circuit in bestowing control of tactics upon counsel. See, e.g., United States ex rel. Agron v. Herold, 426 F.2d 125 (2d Cir. 1970) (failure to act on prejudicial pretrial publicity); Mathis v. Colorado, 425 F.2d 1165 (10th Cir. 1970) (counsel's extensive cross-examination operates as waiver); Mize v. Crouse, 399 F.2d 593 (10th Cir. 1968), cert. denied, 394 U.S. 913 (1969) (failure to object to evidence).

22. In United States ex rel. Gockley v. Meyers, 378 F.2d 398 (3rd Cir.1967), cert. denied, 396 U.S. 847 (1969), counsel explicitly did not object to use of a confession, apparently for sound tactical reasons. Nevertheless, the court remanded for a hearing on the bypass issue and required some showing that the defendant participated in the decision in order to find a deliberate bypass. See also United States ex rel. Snyder v. Mazurkiewicz, 413 F.2d 500 (3rd Cir. 1969). But see United States ex rel. LaMolinare v. Duggan, 415 F.2d 730 (3rd Cir. 1969). Other circuits have also looked for evidence of the defendant's participation before deciding upon a bypass. See, e.g., Marshall v. Rose, 499 F.2d 1163 (6th Cir. 1974) (in-court identification suppression problem); Hale v. Boles, 419 F.2d 389 (4th Cir. 1969). There are also "in-between" cases, where the courts have searched for some minimal indication that a defendant participated in the decision under review in order to satisfy the ambiguous language of Fay and Henry. E.g., United States ex rel. Johnson v. Illinois, 469 F.2d 1297 (7th Cir. 1972), cert. denied, 411 U.S. 920 (1973).

23. Brookhart v. Ianis, 384 U.S. 1 (1966); Spears v. United States, 250 F. Supp. 698 (S.D.W. Va. 1966). To bar counsel from unilaterally pleading his client guilty does not significantly aid the tactical control analysis. To plead guilty is a waiver even more encompassing than the decision to dispense with counsel for trial. It is a 
Control over other areas, such as use of testimony by the defendant or filing a notice of appeal, is unclear. ${ }^{24}$ In the most recent Supreme Court bypass case, Estelle v. Williams, ${ }^{25}$ the habeas petitioner's due process rights were violated when he was dressed in prison garb for his state court trial. The Court refused, however, to grant Williams relief because no objection was made to the use of such clothing. The failure to protest did not warrant "a conclusion that respondent was compelled to stand trial in jail garb or that there was sufficient reason to excuse the failure to raise the issue before trial." ${ }^{20}$ The Court noted that the strict Zerbst knowing and intelligent waiver standard did not

question not of allocating power, but of completely waiving the right to exercise any power over the trial. Leaving the defendant free to control his plea indicates little about his ability to control counsel's pretrial and trial activities.

In Brookhart, for example, counsel, without clear consent from the accused, agreed to proceed on a "prima facie trial." The trial contained only government testimony and lacked any cross examination or defense case. The Court found this process the virtual equivalent of a guilty plea and reversed the conviction for lack of a knowing and intelligent waiver.

24. Compare United States v. Poe, 352 F.2d 639 (D.C. Cir. 1965), with United States v. Jones, 369 F.2d 217 (7th Cir. 1966) (defendant's testimony). See also Nelson v. Peyton, 415 F.2d 1154 (4th Cir. 1969); Grimes v. United States, 396 F.2d 33.1 (9th Cir. 1968).

The ABA Standards provide that pleading, waiver of a jury, and testimony by the accused are decisions for the defendant. THE DEFENSE Function, supra note 7, $\$ 5.2$ (a). "Strategic and tactical decisions" are left with counsel. Id. \$ 5.2(b). The commentary to section 5.2 cites two cases-both involving jury waiver-for the proposition that waiver of a jury and the right of the accused to testify must be by the accused. Neither is apposite. Patton v. United States, 281 U.S. 276 (1930), dealt with the waivability of juries as a general matter, not with the power question; both the accused and his counsel were fully informed of the facts underlying the waiver of a twelve person jury. Id. at 286. Hensley v. United States, 281 F.2d 605 (D.C. Cir. 1960), suggests a proposition different than that stated in the Standards. In Hensley the decision of counsel to waive a jury, made without the knowledge of the defendant, was hcld to bind the defendant. In the direct appeal the court found that the accused acquiesced in counsel's decision by his silence during trial. The result implies that active participation by the defendant is not necessary in a jury waiver decision. See also Parker v. United States, 507 F.2d 587 (8th Cir. 1974), which leaves open the question whether an attorney may waive a double jeopardy defense on behalf of his client.

25. 425 U.S. 50.1 (1976). See also Franeis v. Henderson, 425 U.S. 536 (1976), in which the failure to make timely objection to the composition of a state grand jury according to state law precluded the defendant from federal habeas relief. The state law was given effect because there was no showing of actual prejudice. The case does not directly discuss the attorney-client waiver problems. Justice Brennan cast bitter dissents in both cases, mourning the apparent passing of the Fay rule that waivers must be proved by the state, not disproved by the habeas petitioner. The burden of proof issue, although obviously important in habeas jurisprndence, has little bearing on the theory of control under discussion here. Regardless of who has the burden, there must still be a resolution of the control question. The practical impact of Francis is clearly to broaden the scope of control by counsel. At least in tactical areas counsel's failure to object will apparently suffice to bind a client in the waiver of a federal forum. The impact upon pro se cases is unclear.

26. 425 U.S. at 512. 
apply to mere tactical decisions, that the attorney, once appointed, controlled such decisions, and that the failure to object could have been tactically based. ${ }^{27}$ Despite the imprecision of the opinion, the Court has left counsel free to bind his client in a waiver of the right to seek federal review of virtually all his constitutional claims.

Commentators on the bypass issue have tried valiantly to make sense out of the Fay-Henry abyss. In an attempt to structure the cases various factors have been suggested to determine the allocation of power to deliberately bypass a state remedy. Among them are the time at which the dispute arises, ${ }^{28}$ the intelligence of the defendant, ${ }^{29}$ and the importance of the right in dispute. ${ }^{30}$ Regardless of the test used to justify or explain the control allocation, all assume that split control is appropriate and that permanently defining the boundaries of power is necessary.

Neither the case law nor the literature is helpful in analyzing the problein of who slould control tactical decisions. For example, the problem of time pressures during trial need not be resolved by allocating control to the attorney. Many decisions may be made just as quickly by a defendant as by counsel. ${ }^{31}$ Contending that some decisions must be made quickly does not by itself provide any guidance for allocating the power to make the decision.

Similarly, intelligence of the defendant is not as relevant a basis for allocating power at trial as for deciding a case on collateral attack. A verdict rendered in a state court assumes a status of "rationality" not yet bestowed upon a future trial. The federal judiciary's reluctance to interfere with a state court judgment compels the federal assumption that counsel behaved reasonably at the state trial. As long as some

27. Id. Justice Powell, joined by Justice Stewart, concurred, similarly noting that counsel may not deliberately forego an objection because it is likely to be futile, and expect later to obtain habeas relief. Id. at 515 (Powell, J., concurring). In a footnote the Justices noted that this case involved a "trial-type right" and therefore counsel could bind his client. Id. at 515 n.4 (citing Henry v. Mississippi, 379 U.S. 443 (1965), and Brookhart v. Janis, 384 U.S. 1 (1966)). See also Murch v. Mottram, 409 U.S. 41 (1972).

28. Comment, Calif. L. Rev., supra note 8, at 1269-72. The Comment suggests that participation of the defendant is more feasible before the trial, since time pressures will prevent dialogue during trial.

29. White, supra note 8, at 68; Comment, Harv. L. Rev., supra note 8, at 435.

30. White, supra note 8 , at 68; Comment, Calif. L. Rev., supra note 8, at 126769; Comment, Harv. L. Rev., supra note 8, at 435.

31. This is not to say such decisions will be made more wisely by a defendant than by counsel. Similarly, trial efficiency may be just as easily maintained without regard to the power allocation decision so long as it is clear that as to any particular decision, basic power rests with one party or another. The literature suggests that such allocation must basically be the same for all cases. It is my contention that such rigidity is both unnecessary and unconstitutional. 
intelligent person, be it defendant or counsel, made the tactical waiver decision, finality arguably should attach to the verdict. Thus, unintelligent defendants may be bound by the decisions of competent counsel. While trial preparation is progressing, however, any "active" defendant may justifiably contend that the probleuns of state-federal relationships should take a back seat to the conduct of his trial.

The importance of a right may also be a more rational basis for deciding a habeas problem than for resolving control over a trial tactic. The federal system has historically been reluctant to reverse a state court unless the trial deviated substantially from federal constitutional noruns. Minor deviations from established principals are often overlooked in collateral attack cases. In addition, many tactical decisions are made on issues in which, at least before Faretta, no constitutional rights were at issue. Even the most mundane of tactical disputes, however, nnay trigger serious disagreements between client and counsel.

Finally, although a decision already inade inight justifiably be cast in stone to prevent reversal on collateral attack, such finality arguments do not help make the original power allocation. The judicial focus must change froun finality concerns to the desirability of coercing a defendant into accepting a particular form of defense; and froin waiver of a federal forum to waiver of the assistance of counsel for part or all of the trial. Thus, traditional habeas jurisprudence provides little insight for a trial judge attempting to resolve such a dispute. ${ }^{82}$

\section{B. Ineffective Assistance of Counsel and Mere Tactics}

Attempts have been made to use allegations of ineffective assistance of counsel to provide both the extraordinary circumstances necessary for federal collateral review and a means for discussion of the allocation of control over a trial. ${ }^{33}$ Although such allegations have provided a basis for federal review of state decisions, ${ }^{34}$ they have not opened the door for challenges to counsel's control of pretrial and trial strategy. Contentions that certain decisions were made in disregard of the defendant's wishes are summarily dismissed as frivolous. "Mere tactical decisions" made by counsel without regard to the defendant's

32. The above analysis is for purposes of argument only. Faretta itself compels significant rethinking of the Fay-Henry line of cases. See Section IV(E) infra.

33. For a discussion of the relation between habeas corpus and effective assistance of counsel, see Bines, Remedying lneffective Representation in Criminal Cases: Departures from Habeas Corpus, 59 VA. L. REv. 927 (1973); Waltz, supra note 8; Section IV(C) infra.

34. See, e.g., Chambers v. Maroney, 399 U.S. 42 (1970); Fitzgerald v. Estelle, 505 F.2d 1334 (5th Cir.), cert. denied, 422 U.S. 1011 (1975); Nelson v. Peyton, 415 F.2d 1154 (4th Cir. 1969), cert. denied, 397 U.S. 1007 (1970). 
wishes have not provided a basis for relief under the sixth amendment. $^{35}$

The reasoning of these cases, so far as it goes, is correct. The ineffective assistance of counsel doctrine was created to control the quality of counsel, not the ability of counsel to persuade an "active" defendant to proceed in his best interests. It would turn traditional effective assistance law on its head to say that counsel must assist his client in the presentation of a strategically foolish defense.

The use of effective assistance of counsel cases to deny defendants any ability to control the actions of their counsel is, however, unwarranted. Although it is understandable that appellate courts fear detailed review of the wisdom of counsel's tactical decisions, a defendant desiring to control his counsel's activity is explicitly rejecting the right to effective counsel for part of his trial. The issue thus is not the efficacy of precise appellate quality control, but the standards to be applied in deciding whether to permit a defendant's waiver of effective assistance.

\section{Counsel Assignment and Mere Tactics}

Defendants often attenipt to obtain new counsel; they rarely succeed. Courts have kept tight reins upon the assignment of counsel to indigent defendants and the withdrawal of any attorney-assigned or privately retained-from ongoing litigation. For exaniple, in Brown v. Craven $^{38}$ the defendant and his appointed public defender squabbled almost imnediately after counsel's appointment. The trial court ignored four pretrial requests for new counsel. Eventually, the defendant refused to cooperate in any way with his appointed counsel. Even

35. See Annot., 26 A.L.R. FED. 218, 234-36 (1976). The results in the collateral attack cases, Moran v. Hogan, 494 F.2d 1220 (1st Cir. 1974); Winters v. Cook, 489 F.2d 174 (5th Cir. 1973); Vess v. Peyton, 352 F.2d 325 (4th Cir. 1965); Tompa v. Virginia, 331 F.2d 552 (4th Cir. 1964), are the same as in the direct appeal cases, United States v. Clayborne, 509 F.2d 473 (D.C. Cir. 1974); United States v. Hager, 505 F.2d 737 (8th Cir. 1974). But see Beasley v. United States, 491 F.2d 687 (6th Cir. 1974).

Only the control problem is at issue here. Certainly, meffective assistance could arise when an attorney makes a decision contrary to his client's wishes, regardless of the control dogma. In such situations the courts are careful to state that mere trial tactics, absent an abysmal performance, are for counsel to control. E.g., McQueen v. Swenson, 498 F.2d 207 (8th Cir. 1974).

For a general review of the ineffectiveness rules and their present state of flux, see Finer, Ineffective Assistance of Counsel, 58 CORNELL L. REv. 1077 (1973); Note, Effective Assistance of Counsel for the Indigent Defendant, 78 HARv. L. Rev. 1434 (1965). The harmless error rules may also provide a convenient means of ignoring tactical difficulties. See Bridgeman v. United States, 523 F.2d 1099 (D.C. Cir. 1975); United States v. Clayborne, 509 F.2d 473 (D.C. Cir. 1974).

36. 424 F.2d 1166 (9th Cir. 1970). 
the attorney suggested that he be replaced before the opening of the trial. $^{37}$ The request was denied without inquiry. The Ninth Circuit reversed the conviction and remanded for a new trial because of the failure of the trial court to inake any inquiry into the pretrial indications of attorney-client difficulties. Brown is a good example of the oft-stated rule: "In order to warrant a substitution of counsel during trial, the defendant inust show good cause, such as conflict of interest, a coinplete breakdown in communication or an irreconcilable conflict which leads to an apparently unjust verdict." 38 The defendant, who had inade timely requests for a new attorney and who had been tried while totally refusing to communicate with counsel, was not to be penalized by presuming that the breakdown was intentionally fomented to disrupt the judicial process. ${ }^{39}$ The trial judge's general discretion with

37. Regardless of any positions taken here about the proper role of counsel aftcr Faretta, an attorney should promptly notify the trial court when serious difficulties arise with a client.

In Brown the facts supporting the motion had been evident for some time. To wait until just before trial to move for withdrawal is highly questionable behavior. Faretta implies the need for more. careful judicial scrutiny of the attorney-client relationship. A concomitant increase in the care with which counsel relates to the court should also be required. See Section IV(B) infra.

38. United States v. Calabro, 467 F.2d 973, 986 (2d Cir. 1972), cert. denied, 410 U.S. 926 (1973). See also United States v. Woods, 487 F.2d 1218 (5th Cir. 1973); United States v. Young, 482 F.2d 993 (5th Cir. 1973); United States v. Grow, 394 F.2d 182 (4th Cir.), cert. denied, 393 U.S. 840 (1968); Swope v. McDonald, 173 F.2d 852 (9th Cir.), cert. denied, 337 U.S. 960 (1949). Even total breakdowns, however, have not always led courts to permit counsel to withdraw. In United States v. Munn, 507 F.2d 563 (10th Cir.), cert. denied, 421 U.S. 968 (1974), a difficult client had been through four attorneys, disagreeing with all of them and assaulting three of them. On the morning of trial the last attorney asked to withdraw because of disagreement with his client. He was also one of the assault victims. The withdrawal request was .denied and the conviction was affirmed.

There are also cases where courts misapply Brown's total breakdown test. For example, in Walker v. Commonwealth, 214 Va. 258, 199 S.E.2d 518 (1973), a defendant asked for new counsel before trial because of incompatibility, stood mute at trial, and forbade his counsel to participate in the trial. One might question the willingness of counsel to stand mute, without even asking to withdraw. The conviction was affirmed, the court holding that defendant by his behavior waived his right to effective counsel.

A conflict of interest may also provide a basis for withdrawal of counsel, especially in cases where counsel represents co-defendants. Glasser v. United States, 315 U.S. 60 (1942). When fully informed of the conflict, a defendant may elect to proceed with the attorney anyway. United States v. Armedo-Sarmiento, 524 F.2d 591 (2d Cir. 1975); United States v. Garcia, 517 F.2d 272 (5th Cir. 1975). In such cases the defendant waives his sixth amendment right to conflict-free counsel.

39. See Faretta v. California, 422 U.S. 806, 834 n.46 (1975); cf. United States v. Dougherty, 473 F.2d 1113 (D.C. Cir. 1972) (upholding statutory right to proceed pro se).

The problem of intentional disruption was not discussed in Brown v. Craven, 428 F.2d 1166 (9th Cir. 1970). A trial judge, however, should be free to refuse reassignment of counsel if the defendant's actions were not in good faith. See United States v. Munn, 507 F.2d 563 (10th Cir.), cert. denied, 421 U.S. 968 (1974), discussed at note 38 supra. 
regard to assignment of both original and replacement counsel was left largely unimpaired. Neither the sixth amendment right to counsel nor the due process clause was construed to restrict substantially the trial court's discretion to control the assignment or replacement of counsel..$^{40}$

The nianner in which the Brown court framed the issues is important. The trial court's primary duty was not to satisfy the desires of the represented defendant, but to endeavor to settle the squabble as soon as possible after becoming aware of the problem. ${ }^{41}$ Since counsel was to be replaced only if a complete breakdown in the attorney-client relation had occurred, the defendant was unable to exercise significant control over counsel's behavior.

The restrictive attitude toward replacement of counsel has largely arisen out of fear that randoin changes in counsel will disrupt trial calendars. A trial judge must have significant discretion to settle trial disputes between counsel and client in order to avoid delay of a trial. ${ }^{42}$ Many courts, however, have denied requests for new counsel arising out of disputes over tactics, not on efficiency grounds, but because

40. Nor have the federal courts of appeals taken any steps to exercise their supervisory authority to avoid forcing defendants to accept unwanted counsel. There are holdings indicating that counsel, once retained or assigned, may not be changed over the objections of a defendant. United States v. Seale, 461 F.2d 345 (7th Cir. 1972); Releford v. United States, 288 F.2d 298 (9th Cir. 1961); McKinnon v. State, 526 P.2d 18 (Alas. 1974). Cf. Walters v. United States, 404 F. Supp. 996 (S.D.N.Y. 1975) (substitution of alternative counsel for jury selection only approved). The appellate courts have not forced trial judges, however, to assign counsel initially selected by a defendant.

Peters v. Gray, 494 F.2d 327 (7th Cir. 1974), vividly displays the depth of federal court antagonism to constitutional claims of an accused's right to exercise control over the assigninent of counsel. An attorney, appointed to represent two codefendants, moved to withdraw from one of the cases very shortly after appointment because of a possible conflict of interest. Counsel, noting that one defendant had expressed dissatisfaction with him, asked to withdraw from the unhappy defendant's case. The trial court granted the motion to withdraw on conflict of interest grounds, but only from the case where the defendant had not expressed dissatisfaction. This perverse result was rationalized on the ground that since the protesting defendant had been assigned the attorney first, he was required to keep him. On habeas the Seventh Circuit assumed that the judge's behavior was arbitrary, but found no constitutional violation since the defendant in fact received effective assistance.

41. Other cases indicate that the trial court has a duty to inquire into the causes of disputes that erupt after trial begins. See United States v. Woods, 487 F.2d 1218 (5th Cir. 1973); United States v. Young, 482 F.2d 993 (Sth Cir. 1973); Brown v. United States, 264 F.2d 363 (D.C. Cir.), cert. denied, 360 U.S. 911 (1959).

42. See, e.g., United States v. Dilworth, 524 F.2d 470 (5th Cir. 1975); United States v. Pigford, 461 F.2d 648 (4th Cir. 1972); Jackson v. United States, 412 F.2d 149 (D.C. Cir. 1969). There is general agreement that new counsel need not be appointed on the eve of or during trial. Nor must a court grant a continuance so that counsel retained on the eve of trial may prepare. United States v. Main, 443 F.2d 900 (9th Cir. 1971); United States v. Grow, 394 F.2d 182 (4th Cir. 1968); United States v. Bentvena, 319 F.2d 916 (2d Cir. 1963); State v. Banks, 216 Kan. 390, 532 P.2d 1058 (1975); State v. Slobodian, 120 N.J. Super. 68, 293 A.2d 399 (1972). 
counsel, once appointed, will presumably perform competently ${ }^{43}$ and because defendants have no right to control trial tactics. ${ }^{44}$ In such cases, absent ineffective performance, a conflict of interest, or a breakdown in the attorney-client relation, the defendant is compelled to accept the tactical decisions of his counsel.

Ironically, these traditional rules create incentives for "active" defendants either to decline counsel ${ }^{45}$ and proceed pro se or to squabble with counsel in the hope of obtaining a more syinpathetic attorney. ${ }^{46}$ It is apparent that these rules have been developed without considering the interrelationship of the sixth amendinent rights to proceed either with or without counsel. ${ }^{47}$ The efficiency needs of the judiciary simply do not support the wholesale refusal of the courts to permit defendants to change counsel.

43. For example, in United States v. Young, 482 F.2d 993 (5th Cir. 1973), the defendant charged that his counsel had revealed confidential defense inatters to tho prosecution. The trial court failed to make an inquiry into the mattor. Although finding that such an inquiry probably should have been made, the conviction was affirmed because counsel had handled the trial competently, and communication between counsel and client had remained open.

44. See Vess v. Peyton, 352 F.2d 325 (4th Cir. 1965), cert. denied, 383 U.S. 953 (1966); United States v. Gutterman, 147 F.2d 540 (2d Cir. 1945). In cases where a defendant desiring to control trial strategy is told he may do so only if he proceeds pro se, the courts usually find a waiver of counsel when the defendant elects to represent himself. E.g., United States v. Calabro, 467 F.2d 973, 984-85 (2d Cir. 1972). The implication that changes of counsel may not occur because counsel controls trial strategy was made explicit. Id. at 986-87. See also The Defense Function, supra note 6, \$ 5.2. See generally ABA, CODE OF Professional Responsibility EC 7-7 [hereinafter cited as ABA CODE].

45. Before Faretta v. California, 422 U.S. 806 (1975), was decided, it was generally agreed that defendants had the right, whether constitutional or statutory, to proceed pro se. United States v. Price, 474 F.2d 1223 (9th Cir. 1973); United States v. Dougherty, 473 F.2d 1113 (D.C. Cir. 1972); U.S. ex rel. Maldanado v. Denno, 348 F.2d 12 (2d Cir. 1965); United Statos v. Plattner, 330 F.2d 271 (2d Cir. 1964). For the federal statutory foundation see 28 U.S.C. $\$ 1654$ (1970). See also Comment, SelfRepresentation in Criminal Trials: The Dilemma of the Pro Se Defendant, 59 CALIF. L. REv. 1479 (1971); Note, The Right of an Accused to Proceed Without Counsel, 49 MINN. L. REv. 1133 (1965).

46. Given the disfavor with which courts generally view pro se trials, it is surprising that the cases reveal no sensitivity to the pro se impulses created by the counsel assignment and replaceinent systems presently in use. See United States ex rel. Soto v. United States, 504 F.2d 1339 (3d Cir. 1974); United States v. White, 429 F.2d 711 (D.C. Cir. 1970); Brown v. United States, 264 F.2d 363 (D.C. Cir.), cert. denied, 360 U.S. 911 (1959); State v. Sinith, 215 N.W.2d 225 (Iowa 1974). But see United States v. Plattner, 330 F.2d 271 (2d Cir. 1964). That courts hide the right to proceed pro se from unknowing defendants squabbling with counsel is unjustified under these circumstances.

47. The rules restricting the ability of a defendant to select assigned counsel have also ripened without reference to the right to proceed pro se. It is certainly arguable that if a defendant may proceed pro se, he may also proceed with counsel of choice. See authorities cited at note 3 supra. 
In summary, the pre-Faretta case law on division of control between counsel and client reaches beyond its rational boundaries when used to limit the ability of defendants to control the tactics of their trials. The courts should feel free to chart a new course, unemcumbered by either the strictures of the bypass rules or the limited application of the effective counsel doctrine. New rules of practice should be developed with conscious attention to the riglit of a defendant to proceed pro se. The logical starting point for their development is Faretta v. California.

\section{II \\ Faretta v. California: The Personal Defense AND the Sixth Amendment}

\section{A. The Opinion}

In Faretta the Supreme Court held that the sixth amendment guarantees defendants the right to proceed without counsel. ${ }^{48}$ The Court admitted that its decision appeared to conflict with the language of many right-to-counsel opinions guaranteeing access to legal assistance in order to provide a fair trial. ${ }^{49}$ Chief Justice Burger's dissent concentrated on this apparent inconsistency:

[The] goal [of a fair trial] is ill-served and the integrity of and public confidence in the system are undermined, when an easy conviction is obtained due to the defendant's ill-advised decision to waive counsel. The damage thus inflicted is not mitigated by the lame explanation that the defendant simply availed himiself of the "freedom" "to go to jail under his own banner ..." [citation omitted]. The system of criminal justice should not be available as an instrument of selfdestruction. ${ }^{50}$

The sole measure of a just system, however, is not how well a court, or society at large, feels a case has been tried. The Faretta majority correctly concluded that a defendant's perception of the fairness of his trial is also important." Forcing a defendant to accept counsel "can only lead him to believe that the law contrives against him." ${ }^{22}$ Faretta

48. 422 U.S. at $819-20$.

49. Id. at 832-33.

50. Id. at 839-40. But in Gilmore v. Utah, 97 S. Ct. 436 (1976), the Chief Justice, writing for the Court, permitted a personal waiver of an appeal in a death penalty case, notwithstanding defense counsel's desire to raise serious constitutional challenges to Utah's death penalty statute. The Chief Justice failed to note that his decision simply affirmed the right of Gilmore to proceed pro se on appeal-a stark contrast to his dissent in Faretta.

51. 422 U.S. at 833-34.

52. Id. at 834 . 
resolves the tension between the generalized concepts of fairness discussed by Chief Justice Burger and the defendant's freedom of choice by holding that the sixth amendment affords the defendant a personal right to make his own defense. ${ }^{53}$

The Court found no reason for denying Faretta the right to represent himself. Speaking for the Court, Justice Stewart explicitly rejected the presumed superiority of counsel as a basis for limiting pro se representation:

It is undeniable that in most criminal prosecutions defendants could better defend with counsel's guidance than by their own unskilled efforts. But where the defendant will not voluntarily accept representation by counsel, the potential advantage of a lawyer's training and experience can be realized, if at all, only imperfectly. . . . Moreover, it is not inconceivable that in some rare instances, the defendant might in fact present his case more effectively by conducting his own defense. Personal liberties are not rooted in the law of averages. ${ }^{54}$

Nor was the Court persuaded that administrative difficulties would be significant enough to deny defendants the right to represent themselves. The Court countered the possibility that defendants might disrupt courtroom procedures and decorum by noting that far less severe measures were available to meet deliberate misconduct. ${ }^{55}$ Though the Chief Justice raised the spectre that pro se cases will impose greater burdens on the judicial system, ${ }^{56}$ the majority did not even directly mention the issue, thus implying that such administrative difficulties are not enough to justify denying constitutional rights.

The Court relied heavily on the plain meaning of the sixth amendment:

It is the accused, not counsel, who must be "informed of the nature and cause of the accusation," who nust be "confronted with the witnesses against him," and who must be accorded "conipulsory process for obtaining witnesses in his favor." Although not stated in the

53. Id. at 819-20. Although the sixth amendment resolution is clear, the duc process clause may still dominate some cases. See Sections IV(C)-(D) infra. It is also possible that some rights, such as the right to be free from cruel and unusual punishments, may not be waived by anyone. See Gilmore v. Utah, 97 S. Ct. 436, 439-40 (1976) (White, J., dissenting).

54. 422 U.S. at 834 . It is equally clear that pro se defendants may not rely upon their own lack of expertise to challenge convictions under the sixth amendment. Id. at 834 n.46. It is interesting to note that in Faretta a federal court was reviewing a state conviction. Apparently, the Supreme Court was not convinced that the pro se defendant's intelligence was more relevant than usual simply because the case involved federal-state relations.

55. Id. See Illinois v. Allen, 397 U.S. 337 (1970).

56. 422 U.S. at 845 (Burger, C.J., dissenting). 
Amendment in so many words, the right to self-representation-to make one's own defense personally-is tlus necessarily implied by the structure of the Amendment. The right to defend is given directly to the accused; for it is lie wlio suffers the consequences if the defense fails. ${ }^{57}$

This literal reading, together with the actual Faretta holding, strongly suggests that the sixth amendment provides a represented defendant the right personally to control his defense. ${ }^{58}$

\section{B. Faretta and Partial Waiver}

Interpreting $F$ aretta to mean that represented defendants have a constitutional right to control trial tactics ${ }^{59}$ is a necessary construction of the sixth amendment. The traditional division of control between counsel and client has led to cases in which defendants have proceeded pro se when confronted with a "choice" between a specific appointed counsel and a pro se defense or between total trial control by counsel and a pro se trial..$^{00}$ In such cases the courts have transformed the inability to control or to change counsel into a waiver of counsel-a waiver that is neither voluntary nor intelligent. ${ }^{01}$ Reconciliation of the sixth amendment guarantees of counsel and personal representation requires recognition of the right partially to waive either guarantee. ${ }^{62}$ The traditional doctrines penalize the exercise of either sixth anendment right by auto-

57. Id. at 819-20.

58. The post-Faretta cases have not noted the implications of the opinion. See United States v. Bennett, 539 F.2d 45 (10th Cir. 1976); United States v. Lang, 527 F.2d 1264 (4th Cir. 1975); United States v. Hill, 526 F.2d 1019 (10th Cir. 1975), cert. denied, 425 U.S. 940 (1976); United States v. Wolfish, 525 F.2d 457 (2d Cir. 1975), cert. denied, 425 U.S. 976 (1976); United States v. Swinton, 400 F. Supp. 805 (S.D.N.Y. 1975); Stiner v. State, 539 P.2d 750 (Okla. Crim. App. 1975).

59. Although the Court approved decisions indicating that counsel controls tactical decisions, it carefully noted that

[t]his allocation [of power to counsel] can only be justified, however, by the defendant's consent, at the outset, to accept counsel as his representative. An unwanted counsel "represents" the defendant only through a tenuous and unacceptable legal fiction. Unless the accused has acquiesced in such representation, the defense presented is not the defense guaranteed him by the Constitution, for, in a very real sense, it is not his defense.

422 U.S. at 820-21 (emphasis in original).

60. See, e.g., United States v. Bennett, 539 F.2d 45 (10th Cir. 1976); Stepp v. Estelle, 524 F.2d 447 (5th Cir. 1975); United States ex rel. King v. Sclubin, 522 F.2d 527 (2d Cir.), cert. denied, 423 U.S. 990 (1975); United States v. Corrigan, 401 F. Supp. 795 (D. Wyo. 1975); United States ex rel. Torry v. Rockefeller, 361 F. Supp. 422 (W.D.N.Y. 1973); Jnnior v. Nevada, 91 Nev. 439, 537 P.2d 1204 (1975); Green v. Commonwealth, 211 Va. 727, 180 S.E.2d 531 (1971); People v. Williams, 2 Cal. 3d 894, 471 P.2d 1008, 88 Cal. Rptr. 208 (1970). But see Dearinger v. United States, 344 F.2d 309 (9th Cir. 1965).

61. See Johnson v. Zerbst, 304 U.S. 458 (1938).

62. Similarly, Faretta may compel recognition of the right to cloose assigned connsel. If all counsel are presumed competent, as well as superior in ability to defend- 
matically making the other unavailable. Such a severe penalty ought not be countenanced. ${ }^{63}$ Furthermore, neither the generally superior ability of counsel nor the concern for judicial efficiency compels the traditional all-or-nothing rules.

Trial efficiency concerns have been overstated. Certainly, trial judges must have substantial discretion to control courtroom behavior and to prevent manipulation of procedures by any party. Similarly, it is proper that trial court control over continuances is generally left undisturbed by the appellate courts. ${ }^{\beta 4}$ Efficiency, however, does not explain the judicial hostility to defendant participation in tactical decisions. $^{65}$ Even relatively innocuous requests by defendants to participate in selecting witnesses, ${ }^{86}$ make opening or closing stateinents, ${ }^{87} \mathrm{ex}-$ amine or cross-examine a specific witness, ${ }^{88}$ argue a particular point of law to the court, ${ }^{60}$ or aid in selecting the jury ${ }^{70}$ have been routinely denied. ${ }^{71}$ The routine denial of such narrow requests belies the notion

ants, then arguably a defendant should be allowed to choose from among various trial methods and attorneys in molding his defense. Although a defendant who has no particular concern over the persona of his counsel may be tried with any attorney at the helm, only perversity could justify completely denying other defendants the right to exercise their selectivity. See Tague, supra note 3, at 80-84, 87-99; LaFrance, supra note 3 , at $70-72$.

63. Cf. United States v. Jackson, 390 U.S. 570 (1968) (excessive penalty attached to exercise of right to jury trial).

64. See generally Banfield \& Anderson, Continuances in the Cook County Criminal Courts, 35 U. CHI. L. REv. 259, 267-73 (1968).

65. One certainly may quarrel, however, with the extent of power bestowed upon trial judges. See, e.g., Mayberry v. Pennsylvania, 400 U.S. 455 (1971); Illinois v. Allen, 397 U.S. 337 (1970).

66. United States v. Bridgeman, 523 F.2d 1099 (D.C. Cir. 1975), cert. denied, 425 U.S. 961 (1976); Lauchli v. United States, 432 F.2d 1207 (7th Cir. 1970); Vess v. Peyton, 352 F.2d 325 (4th Cir. 1965), cert. denied, 383 U.S. 953 (1966); State v. Banks, 216 Kan. 390, 532 P.2d 1058 (1975); Shelton v. State, 3 Md. App. 394, 239 A.2d 610 (1968).

67. United States v. Dellinger, 472 F.2d 340 (7th Cir. 1972), cert. denied, 410 U.S. 970 (1973); United States v. Dennis, 183 F.2d 201 (2d Cir. 1950) (L. Hand, J.), aff'd, 341 U.S. 494 (1951); Mosby v. State, 249 Ark. 17, 457 S.W.2d 836 (1970); Moore v. People, 171 Colo. 338, 467 P.2d 50 (1970); Thompson v. State, 194 So. 2d 649 (Fla. 1967); Conway v. State, 15 Md. App. 198, 289 A.2d 862 (1972), cert. denied, 413 U.S. 920 (1973); State v. Velanti, 331 S.W.2d 542 (Mo. 1960); People v. Richardson, 4 N.Y.2d 224, 149 N.E.2d 875, 173 N.Y.S.2d 587, cert. denied, 357 U.S. 943 (1958); State v. Carr, 13 Wash. App. 704, 537 P.2d 844 (1975).

68. United States v. Bentvena, 319 F.2d 916 (2d Cir.), cert. denied, 375 U.S. 940 (1963); State v. Kelly, 210 Kan. 192, 499 P.2d 1040 (1972); Strosnider v. Warden, 245 Md. 692, 226 A.2d 545(1967).

69. State v. McKee, 223 N.W.2d 204 (lowa 1974).

70. State v. Townes, 522 S.W.2d 22 (Mo. 1974); Heard v. State, 126 Ga. App. 62,189 S.E.2d 895 (1972).

71. Nor do judicial efficiency concerns explain denying an indigent the right to select his appointed counsel. See note 4 supra. With respect to monied defendants, 
that judicial efficiency alone requires the present rules. Permitting a defendant to make a closing statement need not be disruptive or inefficient. ${ }^{72}$ Nor is letting a defendant decide which witnesses to call invariably wasteful of the court's time.

It is true that pro se cases may be inore difficult for trial judges to handle than normal trials. ${ }^{73}$ A conscientious judge may spend a significant amount of time leading a pro se hitigant by the hand, ${ }^{74}$ even though appellate courts generally refuse to require such hand holding. ${ }^{75}$ Some requests by represented defendants to participate in their trial may raise legitimate problems of efficiency. But because defendant participation in tactical decisions may create difficulties in some situations does not mean either that all such participation should be prohibited or that procedures to control the new attoruey-chent relationship are inpossible to develop. An agreement drawn before trial between attorney and client, under the instructions or supervision of the trial court, can prevent inidtrial difficulties and reduce inefficiency to or below the level normally associated with pro se trials. ${ }^{76}$

Finally, important efficiency reasons support permitting represented defendants to participate in their own defense. Personal participation in the process is likely to reduce the number of attorney-

delay in selecting counsel (United States v. Inman, 483 F.2d 738 (4th Cir. 1973); United States v. Jones, 369 F.2d 217 (7th Cir. 1966); Tague, supra note 4, at 9697) or numerous changes in counsel (United States v. Munn, 507 F.2d 563 (10th Cir.), cert. denied, 421 U.S. 968 (1974)) may lead to imposition of judicial controls, but the basic notion of free choice of privately retained counsel has remained undisturbed since time immemorial. W. BEANEY, THE RIGHT to COUNSEL IN AMERICAN Courts 14-26 (1955) [hereinafter cited as BEANEY].

72. There is the possibility that a defendant may attempt to make a closing statement in order to "testify" without being subject to cross examination or to the penalties of perjury. See State v. Whitlow, 13 Or. App. 607, 510 P.2d 1354 (1973). However, the possibility that a defendant may try to abuse the riglit to make a closing statement also exists in pro se cases. This abuse arises only when courts and prosecutors permit a defendant to "testify" rather than make a closing argument on the evidence adduced. Thus, a less onerous solution might be to require prosecutors simply to object to testimonial statements.

73. The trial judge may be obligated to intervene more forcefully in pro se trials than in normal cases. See Section IV(C) infra. In addition, a typical pro se defendant does not know very much law, and many judges will spend time helping such defendants. The difficulties confronting pro se litigants are often substantial. See Robbins \& Herman, Litigating Without Counsel: Faretta or For Worse, 42 BrookLYN L. REv. 629 (1976).

74. In Powell v. Alabama, 287 U.S. 45, 61 (1932), a seminal right-to-counsel case, the Government used the practice of judicial hand-liolding in pro se cases as a reason for not requiring counsel. Why courts or the various state and federal prosecutors should be less willing (if they are) to loold liands now than before is explainable only by the historical fact that the institutions providing defense counsel lave become so ubiquitous.

75. Faretta v. California, 422 U.S. 806,834 n.46 (1975).

76. See Section IV infra. 
client disputes generated by defendants who feel powerless to control their fate. ${ }^{77}$ Similarly, defendants using the courtroom as a podium will find their judicial foruin less a provocative stone wall and more a cooperative participant. ${ }^{78}$ Although it is ironic that the Burger Court has rendered a decision whose logical extension approves the right of "political" defendants" to form a partnership with their "radical" lawyers ${ }^{80}$ for the trial of an important case, ${ }^{81}$ many of the chaotic trials

77. See, e.g., United States v. Bridgeman, 523 F.2d 1099 (D.C. Cir. 1975), cert. denied, 425 U.S. 961 (1976); Brown v. Craven, 424 F.2d 1166 (9th Cir. 1970). "Political" trials also generate feelings of helplessness. For example, in United States v. Seale, 461 F.2d 345 (7th Cir. 1972), the court held that the Chicago Seven trial court's refusal to inquire into the defendant's constant indications of dissatisfaction with counsel of record was error. 461 F.2d at 359. Bobby Seale had consistently contended that he was represented by Charles Garry, despite the presence of appearances filed in his case by William Kunstler and other attorneys. The trial judge's failure to inquire into Seale's desires in the matter was held to be error. In effect, the holding required inqniry as to whether Seale was in fact represented only by Garry.

78. The most notorious "political" case of recent history, the chaotic trial of the Chicago Seven, provides an interesting commentary on Faretta. Ont of the series of appellate opimions resulting from that trial, United States v. Dellinger, 472 F.2d 340 (7th Cir. 1972), cert. denied, 410 U.S. 970 (1973); United States v. Seale, 461 F.2d 345 (7th Cir. 1972); and In re Dellinger, 461 F.2d 389 (7th Cir. 1972), at least two issues relevant to the tactical control problem surfaced. First, the Chicago defendants specifically requested to make personal closing statements to the jury. On appeal, the Seventh Circuit quickly disposed of the issue, stating simply that the decision to deny the Chicago defendants permission to close was properly made within the trial judge's discretion. 472 F.2d at 407-08. That result is certainly well within the mainstream of precedent denying represented defendants the right to participate in their trial. Consistent with this holding, the Seventh Circuit, in establishing standards for trial of the numerous contempt citations arising out of the trial, noted that the trial attorneys had no legal obligation to control the behavior of their clients, $461 \mathrm{~F} .2 \mathrm{~d}$ at 399 , and that defendants represented by counsel are "not to be afforded the same latitude of speech and action as an attorney." Id. at 401.

79. It is doubtful that "political" will ever be satisfactorily defined. See Scheflin, Jury Nullification: The Right to Say No, 45 S. CAL. L. Rev. 168, $191-92$ (1972); authorities cited at note 80 infra.

80. See J. Sink, Political Criminal Trials: How to Defend Them (1974); A. Ginger, The Relevant Lawyers (1972); T. Becker, Polmtical Trials (1971).

81. Charles Garry, an attorney who has often defended "political" defendants, has noted the close relationship he tries to attain with his clients. In describing his work with Huey Newton, he said:

The first thing you do when you have a client in a serious case, or even a minor case, is to get to know something about him. It's fundamental-if you don't know your client, you're not going to be able to represent him. You got to know what makes that client of yours tick, what makes him be like he is, what direction he comes from, and what direction he's going. If you don't then you are failing in your basic responsibility as a trial counselyour responsibility to marshall the facts.

GINGER, supra note 80, at 69 . John George, a sole practitioner in Oakland, Cal., states a different feeling about his clients:

At a time like this, a routine client is not looking for participatory democracy.

You say to him, "What are we going to do with this case?" 
of the Vietnam War era could have been more placidly tried if the full import of Faretta had been understood. ${ }^{82}$

Nor does the generally superior ability of counsel justify prohibiting represented defendants from acting as co-counsel..$^{83}$ The general rule is that control of trial decisions rests with counsel in all areas except the guilty plea and perhaps some other "fundamental" decisions. ${ }^{84}$ Yet if a defendant is the repository of wisdom in such crucial areas as pleas, why deny the defendant authority in areas deemed merely tactical? ${ }^{85}$ If the courts are serious about relying upon counsel's tactical superiority, they should require counsel to decide about pleas, confrontation, defense testimony, juries, and representation. The only possible explanation for this odd state of affairs is that courts find some areas in which a defendant's desires, even if irrational, are so important that they supersede the benefits of counsel.

The most compelling reason to reject counsel's expertise as a rationale for the traditional rules lies im Faretta's refusal to rely on the minimal legal abilities of most pro se defendants as a basis for limiting the sixth amendment right to proceed without counsel. When a defendant elects to proceed both with and without counsel, the competence-of-counsel argument has even less weight than it has in total pro se cases. The defendant is not left unassisted to face a well-armed prosecutor, but has a ready supply of advice at his disposal. ${ }^{86}$ The

\footnotetext{
He says, "Well, I came to you for that."

He wants you to make an arbitrary decision that you can save him, not to explore the doubts of his case.

He says, "I know I got a weak case, that's why I come to you."
}

Id. at 374. The differences in attitude reflect one of the more difficult problems with the impact of Faretta. See Section IV(B) infra.

82. See, e.g., United States v. Dougherty, 473 F.2d 1113 (D.C. Cir. 1972). Five of seven defendants charged with vandalizing a Dow Chemical Company office during the Vietnam War moved before the trial to represent themselves. The trial judge denied the motions but granted the defendants the right personally to make opening statements and to testify in narrative fashion. On appeal, the denial of the pro se motions was held to be error. The participation granted the defendants by the court was not deemed to be a sufficiently close analog to total pro se representation to avoid reversal of the convictions.

83. Nor is it consistent to deny defendants their choice of appointed counsel because of the possibility that bad choices will be made. If a defendant may elect to proceed without counsel, it is inconsistent to deny him the right to select counsel. The courts should be delighted when a defendant agrees to the participation of any attorney.

84. There is considerable confusion in this area. See note 24 supra and accompanying text.

85. Justice Stewart, writing for the Court in Faretta, suggested that some defendants might perform more competently than counsel. 422 U.S. at 834.

86. Even if the performance of counsel is likely to be superior, vigorous supervision by clients of the out-of-court activities of counsel may be very beneficial. One study indicates, for example, that personal injury plaintiffs who most closely supervise the performance of their lawyers obtain better court results than passive clients. RosEN- 
crucial inquiry is not the propriety of permitting defendants to proceed as co-counsel, but the legal structure to surround the implementation of Faretta.

\section{III \\ Mixed Representation: Joint AtToRney-Client Presentation of the Defense}

Generally, the judiciary has been unwilling to accommodate the defendant desiring mixed representation at trial. ${ }^{87}$ Although courts have made it clear that they do not feel compelled by the Constitution to provide "mixed representation" upon request, ${ }^{88}$ a variety of special circumstances has produced cases where defendants have acted as cocounsel with their attorneys. A few judges have taken seriously the notion that they have the discretion to grant requests by defendants desiring to shape the presentation of their defense. ${ }^{89}$ Some attorneys, without judicial sanction, have agreed to the tactical desires of their clients. ${ }^{00}$ In addition, some courts endorse the practice of providing pro se defendants with advisory counsel. ${ }^{91}$ At times, these trials have

THAL, supra note 5, at 29-61. Wholesale transfer of this study's results to the criminal forum is not possible, of course. Nevertheless, the inviting hypothesis remains that criminal defendants who actively supervise their attorneys' out-of-court case preparation will do better in court than other defendants. This hypothesis, if true, would lend support to the contention that defendant participation in the tactical underpinning of the defense presentation is a wise course.

87. "Mixed representation" will be used to describe cases in which counsel and client participate jointly in the presentation of the defense.

88. The post-Faretta case law continues to hold that mixed representation is not constitutionally compelled. United States v. Bennett, 539 F.2d 45 (10th Cir. 1976); United States v. Williams, 534 F.2d 119 (8th Cir. 1976); United States v. Lang, 527 F.2d 1264(4th Cir. 1975); United States v. Hill, 526 F.2d 1019 (10th Cir. 1975), cert. denied, 425 U.S. 940 (1976); United States v. Wolfish, 525 F.2d 457 (2d Cir. 1975), cert. denied, 425 U.S. 976 (1976); United States v. Shea, 508 F.2d 82 (5th Cir.), cert. denied, 423 U.S. 847 (1975).

89. See, e.g., United States v. Williams, 534 F.2d 119 (8th Cir. 1976); United States v. Klee, 494 F.2d 394 (9th Cir. 1974).

90. See, e.g., United States v. Terranova, 309 F.2d 365 (2d Cir. 1962) (counsel followed client's instructions to remain mute, presenting no defense and cross-examining no witnesses; ineffective assistance of counsel claim on appeal denied). See also United States v. Bridgeman, 523 F.2d 1099 (D.C. Cir. 1975), cert. denied, 425 U.S. 961 (1976); Duke v. United States, 255 F.2d 721 (9th Cir.), cert. denied, 357 U.S. 920 (1958).

91. Faretta v. California, 422 U.S. 806, 834 n.46 (1975); United States v. Price, 474 F.2d 1223 (9th Cir. 1973); United States v. Dougherty, 473 F.2d 1113 (D.C. Cir. 1972); United States v. Spencer, 439 F.2d 1047 (2d Cir. 1971); United States v. Conder, 423 F.2d 904 (6th Cir.), cert. denied, 400 U.S. 958 (1970); Maguire v. United States, 396 F.2d 327 (9th Cir. 1968), cert. denied, 393 U.S. 1099 (1969); United States v. Stockheimer, 385 F. Supp. 979 (W.D. Wis. 1974), aff'd mem., 534 F.2d 331 (7th Cir. 1976). But see Shelton v. United States, 205 F.2d 806 (5th Cir. 1953); Lopez v. Pritchess, 265 F. Supp. 136 (C.D. Cal. 1967). 
produced interesting interplay between the defendant, the advisory attorney, and the court. Mixed representation has been obtained-albeit indirectly-as a matter of right in inultidefendant trials in which the defendants have taken advantage of their numbers by agreeing that some would accept counsel and others would proceed pro se. ${ }^{92}$ Many of these cases demonstrate that what has been done once can be repeated. The experience provides guidance for the implementation of mixed representation.

\section{A. Defendant Requests for Mixed Representation}

The most difficult mixed representation situations arise when a defendant insists, contrary to the desires of the court or counsel, that his trial proceed in a certain fashion. ${ }^{93}$ These cases place the defendant, the defense counsel, and the court in extraordinary situations. ${ }^{94}$ According to traditional rules the trial court has an obligation to inquire into the nature of any attorney-client disagreement ${ }^{95}$ and to attempt to resolve the dispute; the court has virtually no obligation to replace or tame counsel. ${ }^{96}$ Courts have responded to such crises by urging every-

92. See, e.g., United States v. Bridgeman, 523 F.2d 1099 (D.C. Cir. 1975), cert. denied, 425 U.S. 961 (1976). In United States v. Anderson, Cr. No. 602-71 (D.N.J. May 18, 1973), numerous defendants were tried for breaking into the Selective Service offices in Camden, N.J., and destroying records; some defendants had counsel and others did not. The results were intriguing. See notes 120-22 infra and accompanying text.

93. Many of these cases arise after requests were made by counsel to withdraw or by defendants to obtain new counsel. The affinity of the issues of choice of counsel and control over trial strategy is remarkable. See, e.g., United States v. Bridgeman, 523 F.2d 1099 (D.C. Cir. 1975), cert. denied, 425 U.S. 961 (1976), discussed at notes 100-06 infra and accompanying text.

94. See, e.g., Duke v. United States, 255 F.2d 721 (9th Cir. 1958). The defendant, Duke, an attorney, asked to proceed pro se for preliminary motions but with counsel for trial. The court agreed. At a pretrial conference Duke told the court he wanted Fitzgerald (his counsel) "as an associate." After some discussion the court and Duke agreed that Fitzgerald would be "counsel," but that Duke would be allowed to examine witnesses and argue objections or motions. A request at trial by Duke to make an opening statement was denied. A request to proceed completely pro se was also denied. The Ninth Circuit, in an opinion evincing exasperation with the defendant, affirmed Duke's conviction, holding that hybrid representation was not required and that Duke's behavior constituted a waiver of his right to proceed pro se. It is arguable, however, that the trial court's limitations on the ability of Duke to proceed partially pro se vitiated the pretrial "agreement" and any supposed waiver of pro se rights. Also, although the fickleness of Duke was significant, a last minute request to make the opening statement hardly placed a siguificant impediment into the trial process.

95. See cases cited at note 41 supra.

96. Counsel is simply left free to proceed as he desires. See Vess v. Peyton, 352 F.2d 325 (4th Cir. 1965), cert. denied, 383 U.S. 953 (1966); Spears v. United States, 250 F. Supp. 698 (S.D.W. Va. 1966); State v. Banks, 216 Kan. 390, 532 P.2d 1058 (1975); Shelton v. State, 3 Md. App. 394, 239 A.2d 610 (1968). Of course, if the procedure selected by counsel is ineffective, other remedies may be available to the defendant on appeal. 
one to be nice. ${ }^{97}$ If a defendant decides to insist on his own strategy, he may be forced to proceed pro se even though he has expressed no desire to do so, on the ground that he has "waived" counsel. ${ }^{98}$ The attorney, if locked into the case by the rules restricting withdrawal of counsel or granting of late pro se requests, must decide whether to alienate his client by insisting upon his own notion of his client's best interests or to acquiesce in his client's wishes. The latter choice risks a later charge of ineffective assistance of counsel. ${ }^{99}$

For example, in United States $v$. Bridgeman ${ }^{100}$ one of the defendants in a multiparty conspiracy trial arising out of a prison disturbance desired to place nime inmate witnesses on the stand, despite his trial attorney's objections to the use of some of the witnesses. The court was informed of the disagreement before the presentation of the defendant's case-in-chief and was told that the parties were attempting to work things out. ${ }^{101}$ The attorney called three witnesses, one of whom he had specifically noted hesitancy about putting on the stand. $^{102}$ Only after the testimony of all three witnesses was coinplete and the damage caused by the evidence was clear, did counsel refuse to call any further witnesses. ${ }^{103}$

97. See, e.g., Green v. Virginia, 180 S.E.2d 531 (Ct. App. 1971) (defendant's contempt conviction reversed; trial judge had held him in contempt for failing to agree to counsel's demands).

98. See cases cited at note 60 supra.

99. United States v. Bridgeman, 523 F.2d 1099 (D.C. Cir. 1975), cert. denied, 425 U.S. 961 (1976); United States v. Calabro, 467 F.2d 973 (2d Cir. 1972), cert. denied, 410 U.S. 926 (1973).

100. 523 F.2d 1099 (D.C. Cir. 1975), cert. denied, 425 U.S. 961 (1976). [Ed.] The author was counsel for defendant Johnson on appeal. His complete file of the case is available for reference at his office, Georgetown University Law Center, 600 New Jersey Ave., N.W., Washington, D.C. 20001.

101. Record of Feb. 25, 1974 at 934, United States v. Bridgeman, Cr. No, 85273 (D.D.C. Feb. 26, 1974). Such a dialogue probably met whatever obligations presently rest with a trial court to make an inquiry into an attorney-client squabble. Sec Brown v. United States, 264 F.2d 363 (D.C. Cir.), cert. denied, 360 U.S. 911 (1959). The court, however, was in no position to know the extent of the squabbles occurring in the cell block. Although it might have been appropriate for the court to have made more inquiries about the disagreement, Brown appears to place much of the burden of prompt disclosure upon counsel. Id. at 366.

102. Record of Feb. 23, 1974 at 910-11, United States v. Bridgeman, Cr. No. 85273 (D.D.C. Feb. 26, 1974).

103. The disagreement between the defendant and his attorney over witness calling culminated in a lengthy dialogue between the court, defendant, counsel for the accused, and the prosecutor. It occurred between the time the second witness had testified and the calling of the third witness. Record of Feb. 25, 1974 at 993-1023, United States v. Bridgeman, Cr. No. 852-73 (D.D.C. Feb. 26, 1974). The trial court eventually ruled that the attorney controlled the decision to call all witnesses except the defendant himself. Id. at 1012, 1023. After a bad experience with the third witness, the trial attomey refused to call any more witnesses to the stand, Id. at 1033. The defendant decided to testify, and the defense then rested, wearily. 
The Bridgeman trial illustrates the dilemmas created by application of the traditional rules. Appointed counsel was confronted with a client who desired counsel, ${ }^{104}$ but wanted to control counsel's tactics. The court was confronted with a defendant who refused either to proceed totally pro se or to acquiesce quietly in the notion that counsel controls trial tactics. The defendant was obliged to deal with counsel not of his choosing who indicated an unwillingness to behave accordimg to the defendant's notions of proper trial strategy. Inevitably, the outcome in Bridgeman was unsatisfactory: the judge, constrained by traditional rules, could offer little to subdue the defendant except speeches extolling counsel; the defense counsel acted but partially as his client desired; and the defendant came away convicted and unsatisfied.

As might be expected, appellate courts are highly unlikely to reverse a conviction for any reason related to the "prejudice" caused by defendants who boldly told their lawyers what to do. Whether it be court or counsel, or both, that permitted a defendant to influence trial strategy, convictions have been routinely affirmed. ${ }^{105}$ This was the result in Bridgeman. On appeal it was contended that the trial counsel's acceptance of a significant part of the defendant's trial strategy, without support of a waiver of counsel, violated the defendant's right to effective assistance of counsel. The court responded:

We reject appellant's attempt to reverse his position at trial and now to protest trial counsel's decision to accede to his insistent demands that all nine witnesses be called: he cannot play both sides of the street. He repeatedly tried, with limited success, to overrule his attorney's determinations concerning the calling of witnesses. The fact that deliberation on this issue was lengthy and intense and was conducted under the court's supervision undermines appellant's attack on trial counsel's judgment; that the attorney's position largely prevailed suggests he did not abdicate his fundamental responsibility to manage the defense. ${ }^{106}$

The court, at least in part, concluded that the defendant got what he deserved for his intervention in the trial process.

104. That the defendant never asked to proceed pro se does not answer the more pertinent question: whether the defendant's behavior was equivalent to a waiver of the right either to control the flow of witnesses or to enjoy the effective assistance of an attorney in the limited area of witness flow. See Section IV(A) infra.

105. See, e.g., United States v. Terranova, 309 F.2d 365 (2d Cir. 1962); Duke v. United States, 255 F.2d 721 (9th Cir.), cert. denied, 357 U.S. 920 (1958).

106. $523 \mathrm{~F} .2 \mathrm{~d}$ at $1118-19$. The court's characterization of the dispute-specifically, that judicial supervision was constant and that thorough dialogue on the control problem occurred prior to the witnesses' testifying-is erroneous. See notes 101-03 supra and accompanying text. 
Although such muted hostility does not answer the difficult problems raised by mixed representation cases, it does, ironically, indicate the right direction. Putting aside the pejorative content of opinions like Bridgeman, the cases reveal an unarticulated notion that "active" represented defendants waive their right to effective counsel for the complete trial. To whatever degree appellate courts refuse to permit a defendant's tactical change of heart ${ }^{107}$ to be vindicated on appeal, a decision is made that the constitutional right to effective counsel has been waived for part of the trial by the conduct of the defendant. The general failure of the appellate courts to require specific waiver hearings by trial courts reveals an unwillingness to follow through on the natural consequences of their de facto mixed representation holdings. Although the exact content of such a waiver inquiry is for later discussion, ${ }^{108}$ the idea that a partial waiver of effective counsel is at issue begins the task of placing the mixed representation cases in their proper legal context. ${ }^{109}$

\section{B. Pro Se Defendants and Advisory Counsel}

The anomalies illustrated by the Bridgeman case have their analogs in the mixed representation cases arising after defendants make requests to proceed completely pro se. As a general rule, appointment of advisory counsel to assist a pro se defendant is usually perinitted and sometimes strongly urged. ${ }^{110}$ Advisory counsel is instructed to act fully in accordance with the desires of the defendant. Whether the defendant may use advisory counsel as a spokesman, however, rests in the trial court's discretion. ${ }^{111}$ Thus, where the court has prohibited counsel from speaking on the defendant's behalf, ${ }^{112}$ the defendant must

107. Often the change of heart arises because counsel changes from trial to appeal. That appellate counsel's decision to change strategy in Bridgeman is not permitted to bind the defendant provides an interesting irony to the case.

108. See text accompanying notes $124-45,175-80$ infra.

109. Reported appellate cases with "active" defendants began to appear in noticeable numbers only after World War II. See cases cited at note 4 supra. The relatively recent growth of the right to counsel has now assured most defendants access to counsel. Historically, there has been a shift from almost total pro se representation to almost total representation by counsel. See generally BEANEY, supra note 71 . It should not be surprising to find that once a right to counsel was established, some defendants would find it difficult to accept the new order. That new order, however, has produced a questionable rigidity operating against a defendant's personal participation in his defense.

110. See cases cited at note 101 supra. See also Comment, The Pro Se Defendan's Right to Counsel, 41 U. CIN. L.R. 927 (1977); Note, The Jailed Pro Se Defendant and the Right to Prepare a Defense, 86 YALE L.J. 292 (1976).

111. See cases cited at note 91 supra.

112. United States v. Conder, 423 F.2d 904 (6th Cir.), cert. denied, 400 U.S. 958 (1970). See also United States v. Pomeroy, 485 F.2d 272 (9th Cir. 1973). Cf. cases cited at note 60 supra (defendant proceeds pro se when confronted with "choice" be- 
either do all the talking himself or risk loss of the right to proceed pro se. ${ }^{118}$ In essence, use of the pro se route to compel mixed representation has occurred, but as a matter of grace rather than of right.

Despite the rigidity of the developing rules, some cases are reported in which defendants and advisory counsel have jointly presented a case. ${ }^{114}$ Later claims that such mixed representation denied a defendant his right to proceed pro se have been net with expected disfavor. ${ }^{115}$ In this context, at least, the finding of a partial waiver of sixth amendment rights may be based on some facts in the record. For example, in Bayless $v$. United States ${ }^{116}$ the defendant proceeded pro se with a retained advisory counsel during the pretrial period. For the trial the defendant noted that "he wanted counsel to fully represent him, except that he himself was to have the right, after his counsel had cross-examined witnesses, to himself further cross examine them."117 The trial court's acceptance of this arrangenient was affirmed on appeal, the Ninth Circuit noting that the defendant was pernitted to proceed pro se to the exact extent he desired. ${ }^{118}$

To whatever extent courts refuse to permit pro se defendants to use their advisory counsel as spokesmen, or find waiver of the right to proceed pro se when defendants turn to advisory counsel for such assistance, the same dilemmas arise as in cases where counsel was imitially retained or assigned. If the court denies access to partial counsel an effective waiver of counsel is forced upon the defendant. If partial reliance upon counsel leads to a judicial demal of pro se activity, an effective waiver has also occurred. The failure of the judiciary to inake careful inquiry into the waiver problems is a serious oversight.

tween specified appointed counsel and a pro se defense or between total trial control by counsel and a pro se trial).

113. A court that relies on partial waiver of counsel to grant the type of mixed representation in which advisory counsel may speak on defendant's behalf may find it inpossible to return later to a total pro se condition. See, e.g., People v. Lindsey, 17 IIl. App. 3d 137, 308 N.E.2d 111 (1974). The trial court initially permitted the defendant to proceed pro se with an assistant able to speak during the trial, but later withdrew counsel's right to participate. The conviction was reversed on the correct ground that the defendant had made only a partial waiver of counsel. See generally Coininent, Self-Representation in Criminal Trials: The Dilemma of the Pro Se Defendant, supra note 45.

114. United States v. Poineroy, 485 F.2d 272 (9th Cir. 1973); United States v. Dougherty, 473 F.2d 1113 (D.C. Cir. 1972); Bayless v. United States, 381 F.2d 67 (9th Cir. 1967). See also United States v. Conder, 423 F.2d 904 (6th Cir.), cert. denied, 400 U.S. 958 (1970).

115. United States v. Pomeroy, 485 F.2d 272 (9th Cir. 1973).

116. 381 F.2d 67 (9th Cir. 1967).

117. Id. at 71 .

118. Id. 


\section{Multiple Defendant Cases}

The only instances in which defendants have been successful in compelling a court to grant a species of mixed representation are multiple defendant cases. ${ }^{119}$ For instance, in United States v. Anderson ${ }^{120}$ numerous defendants were tried on charges of breaking into the Camden Selective Service Offices and destroying files; some of the defendants proceeded pro se, and others retained counsel. ${ }^{121}$ As a result of the mixed representation, the defendants as a group were able to present both inoving personal appeals and precise legal arguments in a way not available to the usual single defendant. ${ }^{122}$ One searches in vain for a reason why co-defendants may command the court to provide them with mixed representation at trial while single defendants may not. Although soine co-defendants have differing interests requiring independent decisions by different counsel, many co-defendants do proceed to trial with common goals. Particularly in situations where the defendants act as a coherent group, they may make effective partial waivers of both counsel and the right to proceed pro se if certain of them totally waive while others totally accept counsel.

The inconsistencies in the present system are resolvable only by accepting the clear consequence of Faretta that the scope of defendant participation in the trial must be decided by the defendant. The real issues for the future concern not the scope of proceedings in which counsel inust be provided, ${ }^{123}$ but the implementation of the defendant's right to shape the presentation of his defense. Redefining the waiver

119. E.g., United States v. Bridgeman, 523 F.2d 1099 (D.C. Cir. 1975), cert. denied, 425 U.S. 961 (1976); United States v. Anderson, Cr. No. $602-71$ (D.N.J. May 18,1973 ).

120. Cr. No. 602-71 (D.N.J. May 18, 1973). The trial resulted in an acquittal.

121. Among retained counsel was David Kairys of Philadelphia, who kindly permitted my research assistant to review parts of the case transcript.

122. The case was an extraordinary example of how gifted speakers as defendants can effectively aid technically competent counsel in a mixed representation situation. In addition, the case presented an interesting study in jury nullification. The pro se defendants were permitted to discuss jury nullification in their opening and closing statements. In addition, the involvement of government agents in the preparation of the break-in led the judge to instruct the jury that they could acquit if they found that "the over-whelming participation by ... Government agents or informers . . . was so fundamentally unfair [as] to be offensive to the basic standards of decency, and shocking to the universal sense of justice." Record at 8729, United States v. Anderson, No. 602-71 (D.N.J. May 18, 1973).

123. See generally Wolff v. McDonnell, 418 U.S. 539 (1974); Ross v. Moffitt, 417 U.S. 600 (1974); United States v. Ash, 413 U.S. 300 (1973); Gagnon v. Scarpelli, 411 U.S. 778 (1973); Argersinger v. Hamlin, 407 U.S. 25 (1972); Kirby v. Illinois, 406 U.S. 682 (1972); In re Gault, 387 U.S. 1 (1967); Douglas v. California, 372 U.S. 353 (1963); Gideon v. Wainwright, 372 U.S. 335 (1963). See also Criminal Justico Act of 1964, 18 U.S.C. § 3006A (Supp. 1976). 
standards governing a defendant's sixth amendment rights to proceed both pro se and with counsel is the first step.

\section{IV}

\section{IMPLEMENTING MiXED REPRESENTATION}

\section{A. Waiver and Notice}

The Court in Faretta carefully held that the right to proceed pro se has a basis in the sixth amendment independent from that of the right to be represented by counsel. ${ }^{124}$ When a defendant agrees to have counsel appointed, he in essence waives his right to proceed pro se. Similarly, when a defendant proceeds pro se, he waives his right to be represented by counsel. The complimentary nature of the rights makes waiver decisions somewhat peculiar. This is especially true when defendants select a mixed form of representation, thereby waiving and accepting certain aspects of each right.

For example, the court of appeals in the Bridgeman case, ${ }^{125}$ without careful discussion of the issue, essentially held that the defendant waived part of his right to effective counsel by his demands that counsel present certain witnesses. The appellate court should have inquircd whether the defendant made a knowing and intelligent waiver of counsel, at least for the limited task of selecting witnesses. ${ }^{126}$ Failure to make such an inquiry ignores the teaching of Johnson $v$. Zerbst ${ }^{127}$ that counsel is deemed waivable only by a knowing and intelligent decision ${ }^{128}$ or by behavior making the implementation of the right impossible. ${ }^{129}$ There is no theoretical reason why a partial waiver of counsel is any less crucial than a total waiver. In fact, where defendants have asked and been permitted to proceed pro se in the middle of their trials, the Zerbst standard has been applied. ${ }^{130}$ Thus, in Bridgeman an effective waiver should not have been found, at least not for the reasons given in the opimion. ${ }^{181}$

124. 422 U.S. at 819 n.15.

125. See notes $100-06$ supra and accompanying text.

126. The court of appeals refused to reconsider the case when the waiver issues raised by its opinion were pointed out in a petition for rehearing. Order of Jan. 9, 1976. The Supreme Court denied certiorari on the same issue. 425 U.S. 961 (1976).

I27. 304 U.S. 458 (1938).

128. Id. at 464. See also Brewer v. Williams, 45 U.S.L.W. 4287, 4292 (U.S. Mar. 23, 1977).

129. United States v. Munn, 507 F.2d 563 (10th Cir.), cert. denied, 421 U.S. 968 (1974); United States v. Dougherty, 473 F.2d 1113 (D.C. Cir. 1972). See also Illinois v. Allen, 397 U.S. 337 (1970). Waiver by obstreperous behavior was not at issue in the Bridgeman case.

130. See, e.g., Watts v. United States, 273 F.2d 10 (9th Cir. 1959).

131. There was a lengthy dialogue between the court and the defendant on the witness control issue. It occurred after the testimony of the crucial second witness 
Moving in the opposite direction-that is, permitting a pro se defendant to obtain counsel for some or all of his trial-presents more difficult theoretical problems. No case has ever held that waiver of pro se rights must be made on the Zerbst standard. Even after Faretta it is not obvious that pro se rights, in the average case where counsel is assigned and accepted, must be specifically waived on the record at all. Nor is it well established that routine notice must be given to defendants that there is anything to waive. In fact, the preFaretta cases generally hold the opposite. ${ }^{182}$ Although the notion of counsel's superior knowledge and the concern for judicial efficiency may no longer control the ability to grant or deny total or partial pro se requests, it does not automatically follow that notice of the right to proceed pre se, or a particularized finding of waiver of pro se rights, must be made in every case. It could be argued that persons requesting total or partial pro se representation should be accommodated for the reasons already stated, but that no effort should be made to encourage either total or partial pro se proceedings by routine notifications at arraignment. ${ }^{133}$ Such a theory, however, is untenable. Although overt waiver inquiries are not required for every right granted by the Constitution, the right to proceed pro se may not be deemed one of those quiescent rights. Several factors indicate that only a knowing and intelligent decision will support a waiver of pro se rights.

The development of the appropriate manner to present the defense is a process reserved to the defendant. ${ }^{134}$ As a general proposition, those rights subject to waiver only under the Zerbst standards are closely related to the trial itself. They are the areas in which the courts have deemed it absolutely essential to protect the defendant's freedom to be irrational. Thus, a defendant may waive a full trial only after a knowing and intelligent decision, ${ }^{135}$ may be reinoved from the courtroom only after being clearly warned of his right to remain and

for the defense. See note 103 supra and accompanying text. The implication in the opinion that the dialogue occurred earlier is incorrect. See 523 F.2d at 1118. If the dialogue had occurred earlier it might have provided the basis for a Zerbst waiver. The defendant said that it was his case and that he had to take chances with inmates as witnesses because they were the only people at the scene. Record of Feb. 25, 1974 at 1008-09. One further question like, "Do you waive the right to effective counsel for purposes of witness selection?" could have ended the matter.

132. United States ex rel. Soto v. United States, 504 F.2d 1339 (3d Cir. 1974); United States v. White, 429 F.2d 711 (D.C. Cir. 1970); Brown v. United States, 264 F.2d 363 (D.C. Cir.), cert. denied, 360 U.S. 911 (1959); State v. Smith, 215 N.W.2d 225 (Iowa 1974). But see United States v. Plattner, 330 F.2d 271 (2d Cir. 1964).

133. This assumes that no substantial disagreement has surfaced between counsel and chent. In the squabble cases a duty of inquiry exists which might require, in rare cases, notification of the right to proceed pro se. See cases citcd at note 41 supra.

134. Faretta v. California, 422 U.S. 806, 819-20 (1975).

135. Brookhart v. Janis, 384 U.S. 1 (1966). 
confront witnesses, ${ }^{136}$ and, as already stated, may waive counsel only after being told of his right to representation. ${ }^{137}$ Nothing is more crucial to the presentation of a trial defense than who will do the speaking. The policies supporting Zerbst require that the pro se right be waived only after a full description of its holding is provided the defendant. ${ }^{138}$

None of the Supreme Court waiver cases refusing to apply Zerbst apply to the pro se setting. In Schneckloth v. Bustamonte ${ }^{139}$ the Court held that the stringent Zerbst waiver standards do not apply to the obtaining of consent to a noncustodial search of an automobile by the police. Rather, the question of consent is to be analyzed in light of the totality of circumstances. Actual knowledge of the right to refuse to permit the search is only one factor to be taken into account in making the waiver finding. ${ }^{140}$ In distinguishing Zerbst Mr. Justice Stewart, writing for the Court in Schneckloth, said:
[A] strict standard of waiver has been applied to those rights guaran- teed to a criminal defendant to insure that he will be accorded the greatest possible opportunity to utilize every facet of the constitu- tional model of a fair criminal trial. Any trial conducted in deroga- tion of that model leaves open the possibility that the trial reached an unfair result precisely because all the protections specified in the Con- stitution were not provided. A prine example is the right to counsel. For without that right, a wholly innocent accused faces the real and substantial danger that sinply because of his lack of legal expertise he may be convicted. ${ }^{141}$

136. Illinois v. Allen, 397 U.S. 337 (1970).

137. Cf. Boykin v. Alabama, 395 U.S. 238 (1969). Acceptance of pleas may be compared to control of a trial. Boykin emphasizes the importance of defendant's understanding the natnre of a trial before a guilty plea may be entered. By analogy, a defendant should be told that he may speak for himself if he elects not to plead guilty. Pleading is like selecting oneself as spokesman.

138. In addition to looking directly at the fundamental nature of the decision involved, the Faretta Conrt looked to the first amendment to support its refusal to impose a particular mode of trial presentation upon a defendant making a decision to proceed pro se. 422 U.S. at 834 n.45. It is also highly significant that the doctrine of harmless error was not applied in Faretta. Both these aspects of the case indicate the special nature of the pro se right: it is taken so seriously that its irrational exercise may overcome the strong judicial preference for trial with counsel for all defendants but those deemed incompetent to make a waiver decision at all.

139. 412 U.S. 218 (1973).

140. Id. at 227 .

141. Id. at 241. The Conrt noted that the fourth amendment search and seizure guarantees were not a fundamental aspect of the trial process and that they should therefore not be surrounded with strict waiver standards. Id. at 242-43. Cf. Stone v. Powell, 96 S. Ct. 3037 (1976) (where state gives a fair opportunity to litigate fourth amendment claims, those issues cannot again be raised in a federal habeus corpus proceeding becane of the limited justification for the exclusionary rule); see text accompanying note 194 infra. 
Although pointing to the trial as the Zerbst controlled area, the suggestion that fairness of the trial is the objective protected by Zerbst causes some difficulty; it could be argued that Faretta does not protect the right to a fair trial but endangers it. ${ }^{142}$

Three reasons compel that this reading of Schneckloth, Zerbst, and Faretta be rejected. First, refusal to notify defendants of pro se rights for fairness reasons conflicts with Faretta's holding that a defendant may proceed pro se, even if his desire is irrational and likely to result in an objectively unfair trial. Faretta thus suggests that the balancing approach used in fourth annendment cases is inappropriate in determining the standards that govern waiver of the right to proceed pro se. That the court may prefer a certain choice provides an unsatisfactory basis for failing to require an inquiry into the knowledge and intelligence upon which the defendant's choice is based. In fact, Faretta, Zerbst and Schneckloth work well together if the protected area is defined as the core of choices surrounding the mode by which a defense is presented, rather than merely the due process notion of a fair trial.

Second, it would be anomalous if a defendant could obtain mixed representation, on the one hand, by accepting inost of counsel's assisttance and then waiving part of it under Zerbst; and, on the other, by demanding to proceed pro se and then waiving part of his pro se rights without any waiver imquiry at all. The two rights are so intimately related that a waiver of either should be based upon the same standard. ${ }^{143}$ The Court's reference in Schneckloth to waiver of counsel as a Zerbst controlled area should be sufficient to resolve the Faretta question as well.

142. To this extent Schneckloth leaves us near the starting blocks. The federal cases are also unclear on whether a trial court must notify a represented defendant of his personal right to decide whether to testify at trial if his counsel indicates a desire not to use him, or of his personal right not to testify if his counsel indicates a desire for him to do so. Presumably, cases requiring such notice at trial would tell us that it is not solely the notion of a fair trial that the waiver concepts protect, but also the defendant's perception of his chance for a fair trial. In one case, an appellant contended he should have been warned when his testimony became highly incriminatory. United States v. Escandar, 465 F.2d 438 (5th Cir. 1972). The difficulty of implementing such a rule led the court to affirm the conviction, holding aside the question whether warnings might generally be required. See Section IV(C) infra for the implications of the fifth amendment cases in pro se trials.

143. This intimacy would not obviously exist when a defendant elects to stand mute and to waive both his right to counsel and his right to proceed pro se. Cf. United States $e x$ rel. Testamark v. Vincent, 496 F.2d 641 (2d Cir. 1974) (conviction affirmed where defendant, denied his request of a particular lawyer, stood mute at trial, refusing both assigned counsel and pro se representation). The judiciary's choice of attorney, however, should not control a defendant's decision to waive both counsel and pro se representation, as well as the rights to confront witnesses, present a defense, and testify. Such a defendant would still force the state to prove its case. As long as Zerbst waiver inquiries are properly made, such a "mute" trial appears perfectly legitimate. See United States ex rel. Davis v. Jennings, 414 F. Supp. 544 (E.D. Pa. 1976). 
Finally, telling a defendant that he may have counsel does not provide all the imformation necessary to decide the pro se question. The routine assignment of counsel, often prior to any appearance before a judge, commonly results in a fait accompli by the time arraignment is completed. In addition, full description of the risks of pro se representation is an integral part of the decision to accept or reject counsel. To whatever degree the courts feel that partial or complete pro se representation is likely to be an unwise choice, they are free gently to discourage defendants from proceeding alone. ${ }^{144}$ The right of a judge to discourage, however, may not also be the basis for hiding the existence of the right. Rather, the freedom of the courts to discourage pro se trials is part of the underlying knowledge upon which a defendant must base his imtelligent choice about use of counsel. ${ }^{145}$

Admittedly, there are limits to the specificity of notice that can be given at arraignment. In fact, to impose a completely rigid set of warnings upon a defendant at that stage would be unwise, because viable choices about modes of defense presentation may not yet be known. A defendant may easily be told, however, that he may proceed pro se, by counsel, or in combination; ${ }^{146}$ that if counsel is desired in any capacity that choice must be made before trial to avoid undue delay; and that if counsel is accepted the defense team will not be permitted to change strategies in the 1middle of a trial when that course of action would cause undue confusion and delay. ${ }^{147}$

144. See United States v. Plattner, 330 F.2d 271 (2d Cir. 1964). The word "gently" is advisedly used. Care must be taken to avoid jeopardizing a Zerbst waiver of pro se rights or of counsel by overly strong judicial remarks.

145. The Second Circuit has accepted this approach, requiring trial judges to inquire as to defendant's choice between representation by counsel and proceeding pro se. United States v. Plattner, 330 F.2d 271 (2d Cir. 1964). Cases from the D.C. Circuit appear to suggest that a defendant who unakes a justified complaint about his attorney may have a right to be informed of his pro se right. See United States v. Jones, 514 F.2d 1331 (D.C. Cir. 1975); Brown v. United States, 264 F.2d 363 (2d Cir. 1959).

146. The latter option assumes that defendants may proceed as of right with mixed representation-a position not yet adopted by the courts. See cases cited at note 88 supra. Assuming, however, that Faretta entitles defendants to mixed representation, then a court that affords the accused notice of his right to proceed pro se should also notify him of his right to mixed representation. If total and partial waivers of counsel and total waivers of the right to proceed pro se must be made on the Zerbst standard, then partial pro se waivers cannot be distinguished.

147. See Dearinger v. United States, 344 F.2d 309 (9th Cir. 1965) (midtrial change of plans acceptable where no significant disruption or delay likely to result). The court's discretion to permit midtrial changes should be exercised as freely as possible because of the importance of the rights involved; however, the need of trial courts to control their dockets will eventually overtake the desires of some defendants to alter their pretrial agreements. See Section V(D) infra.

The pro se notice and waiver questions raise by implication a whole series of other waiver-notice questions. If a court must routinely notify a defendant of his right to proceed pro se or in mixed form, why should a defendant, even though represented by counsel, not be notified of a wide variety of other rights or strategic choices? Al- 
Because the assignment question generally arises very early in the trial process, only the court, an agent of the court, or an attorney, is ordinarily available to provide basic information to the defendant upon which he may base a representation decision. Although early notice by the trial court to the defendant of the available options should be required, determining the exact nature of any combimed representation may be postponed until after arraignment, when counsel has had a chance to speak to the defendant in some detail about his upcoming trial. Any pretrial hearing at which the waivers necessitated by mixed representation find their way into the record may well be influenced by advice of counsel on a number of issues.

\section{B. The Role of Counsel}

The advent of mixed representation and the notice-waiver doctrines surrounding it creates two significant sets of problems for the Bar. First, to the extent that time linitations prevent trial courts from describing many details of the trial process to defendants, the burden of transferring information will shift to defense counsel. Describing the scope of this duty is important not only for the implementation of mixed representation, but also for proper delineation of sixth amendment standards for effective assistance of counsel. Second, Faretta compels the organized Bar to revise its ethical norms. The existing rules on acceptance and withdrawal from criminal cases and control of tactics need to be carefully examined.

\section{The Duty to Provide Information}

Faretta requires that counsel act as an assistant as well as a boss. Playing a secondary role in part of the trial, while functioning as advocate in those spheres relinquished to him by the defendant, places counsel in a complex position. ${ }^{148}$ The trouble many lawyers will ex-

though a general statement that a defendant has the right to proceed pro se in whole or in part theoretically covers any possible area of the trial, why not describe in some detail the various parts of the trial process and the multitude of functions that a defense attorney has traditionally performed? At some point limitations on judicial time will prevent detailed descriptions of the trial process to defendants at arraignment. Notification of the right to proceed pro se or in a mixed fashion, together with an admonition to defense counsel to review fully the trial process with his client, should suffice for constitutional purposes. This is not to say, however, that detailed judicial notice might not be required later if a problem should arise, or that a defendant proceeding entirely pro se might not have to be given more information by the court than a represented defendant. See Section IV(D) infra.

148. But schizophrenic advocacy is not a novel role for counsel. His duty to represent his client zealously obligates him at times to follow his clients wishes even though he thinks them unwise and at other times to pursue what he believes are his client's best interests. See generally ABA CODE, supra note 44, Canon 7; M. FREEDMAN, LAWYER'S ETHICS IN AN ADVERSARY SYSTEM 27-42 (1975). 
perience in adapting to their new role dichotomy is the most difficult long-term problem emerging from Faretta. The obligation to follow a defendant's desires in trial preparation and strategy has few clearly defimable limits. ${ }^{149}$ The trial of a mixed representation case may present the attorney with a moral dilemma so serious that a conflict of interest arises, ${ }^{150} \mathrm{~m}$ this case permissive withdrawal is the only realistic solution available to the unhappy attorney. To the extent that the courts refuse to permit withdrawal under such circumstances, ${ }^{151}$ Faretta will in effect substitute some of the tensions of defendants with those of counsel. ${ }^{152}$

The developing torts doctrine of informed consent provides a useful model for the new ethical role of counsel. ${ }^{153}$ In general, the

149. See The DefENSE FunCrion, supra note $6 \S 3.7$. The most obvious limits are those associated with the obligation not to commit criminal offenses, such as threatening witnesses or tampering with a jury.

150. See cases cited at note 38 supra; The Defense Function, supra note $6, \S$ $3.5(\mathrm{a})$.

151. If past performance is any guide, see Section I supra, courts are likely to refuse such withdrawals, especially if the motions are made close to the date set for trial.

152. It is appropriate that those who operate the courts and perform within them, as well as the defendants, accept some of the difficulties caused by pursuing a trial fair in the mind of the defendant as well as fair to the court. The increased tension placed upon counsel by Faretta, together with its personalization of the defense, do, however, coalesce to command additional flexibility in the assignment and change of counsel.

153. Disputes over the proper roles of professionals and their clients rage not only in law, but also in psychiatry, medicine, and industrial relations. A spectrum of relationships from the guiding professional and the subservient client to the demanding client and the acquiescing professional is described in the literature in all these areas. The most recent description of the general problem, along with a compendium of citations to the literature, may be found in D. RosenTHal, supra note 5, at 7-28. Rosenthal describes the polar types of clients as follows:

According to the traditional theory the client who is passive, follows instructions, and trusts the professional without criticism, with few questions or requests, is preferable and will do better than the difficult client who is critical and questioning. .... The participatory theory promotes an active strategy assuming that it is primarily the client's own responsibiility to grapple with the problem. Instead of delegating responsibility to the professional and leaving the decisions to him while being kept only minimally informed, the participating client seeks information to help him define his problem and what he wants to accomplish, rather than waiting to be told how to proceed.

Id. at 13-14.

Rosenthal's conclusion that the participating client has a beneficial impact on the outcome of his own litigation suggests that much more study needs to be done on the impact of the attorney-client relationship upon case outcome. The lack of such studies in the criminal field makes it impossible to reach any couclusions about the impact of Faretta in individual cases. The prevalence of disputes in many server-client areas about the proper role of clients, however, should support the use of informed consent theories in the criminal defense context. The informed consent doctrine intimately involves considerations of the value of active and passive clients. For a general discussion of the doctrine see J. KATZ, EXPERIMENTATION WITH HUMAN BeIngs 523-734 (1972); 
doctrine requires doctors to inform patients of material risks prior to undertaking a course of medical treatment. The definition of material risk varies in the case law from risks that would be disclosed by a reasonable practitioner in the community, to dangers that a reasonable nuan would regard as material to the medical decision under scrutiny. ${ }^{154}$ Whichever standard applies, the doctrine requires that a patient be permitted to refuse treatment, even for irrational reasons, once informed of the material risks. The analogy to Faretta is compelling. ${ }^{165}$

For example, suppose that the previously suggested niode for assignment of counsel ${ }^{156}$ had been followed in Bridgeman; ${ }^{157}$ namely, that the defendant had elected at arraignment to permit the appointnient of counsel, but had left open the possibility that he would not permit counsel total control over the trial. Suppose further that as pretrial preparation of the case developed, the defendant told his lawyer that he wanted nine witnesses called. Other than to interview the suggested witnesses, what are the attorney's obligations?

Traditionally, an attorney appointed to represent such a defendant would simply decide whether the testimony of any or all of the proposed witnesses would be used at trial. ${ }^{168}$ Under an informed consent

Capron, Informed Consent in Catastrophic Disease Research and Treatment, $123 \mathrm{U}$. PA. L. Rev. 340 (1974); Comment, Informed Consent-A Proposed Standard for Medical Disclosure, 48 N.Y.U.L. Rev. 548 (1973); Note, Informed Consent and the Dying Patient, 83 YAle L.J. 1632 (1974) [hereinafter cited as Note, Informed Consent and the Dying Patient].

154. See Note, Informed Consent and the Dying Patient, supra note 153, at 1636 . 43. The first standard requires expert testimony on local community medical norms and relies upon medical practitioners to set their own standards. The more modern cases have moved to the second test, which requires no expert testimony, but instead relies upon the jury to balance the magnitude of the risk with the seriousness of the medical problems involved.

155. The most important difference between law and medicine is remedy. Harm resulting from failure of a doctor to disclose risks may be compensated with damages should the unstated risk occur; this remedy, however, is likely to be unavailable to the average defendant in a criminal case. Very often the criminal defendant turned civil plaintiff will not be able to prove that any harm resulted from the civil wrong. Although nominal damages might be appropriate, they will not deter malpractice. Reliance on punitive damages is risky. Finally, the most important concern of the defendant-plaintiff may be freedom rather than money. Civil remedies will not meet this need. A defendant inust look to the appellate courts to structure deterrent rules to control overreaching by trial lawyers. Such rules are likely to arise in appellate disputes over Zerbst-Faretta waivers. Bar disciplinary proceedings may be helpful over the long haul, but defendants in individual cases languishing in jail will take little solace from the knowledge that their old attorneys are now selling peanuts.

156. See text accompanying note 147 supra.

157. See notes 100-06 supra and accompanying text.

158. The traditional obligation of the attomey to discuss the matter with the client in no way dimmishes counsel's equally strong dnty to present the case in the way most likely to meet the client's "best interest." See generally ABA CODE, supra note 44 , Canon 7. 
model the attorney should reveal to the defendant the reasons why certain witnesses should be used and others should not, the danger in the recommended course of action, the alternatives to the recommended path, and the benefits likely to accrue from each strategy. The final choice as to both the calling of the witnesses and the selection of the person to elicit the testimony would be left with the accused. Taking the liberty of substituting legal for medical terninology in a quotation from a inedical malpractice opinion, the attorney would be guided by the following general restrictions:

[I]n due deference to the [client's] right to self determmation, a [lawyer] is bound to disclose all the known material risks peculiar to the proposed procedure. Materiality may be said to be the significance a reasonable person, in what the [lawyer] knows or should know is his [client's] position, would attach to the disclosed risk or risks in deciding whether to submit or not to submit to [the lawyer's recommendations]. Among the factors which point to the dangerousness of a [legal tactic] are the severity of the risk and the likelihood of its occurrence. ${ }^{159}$

Defining the term material risk, and thus defining the standard of disclosure, might be sliglitly more difficult in law than in medicine. Insofar as medical risk is scientifically discernible, choices may be more easily described to a patient than a client. ${ }^{160}$ The informed consent theory, however, relying on concepts of reasonable behavior, is flexible enough to absorb whatever predictability problems arise. That mucl medical risk cannot be described scientifically has not prevented the development of informed consent theory in tort.

Informed consent theory fits snugly with the basic notion of Faretta that the preparation of the defense is controlled by the ac-

159. Wilkinson v. Vesey, 110 R.I. 606, 627-28, 295 A.2d 676, 689 (1972), discussed in Note, Informed Consent and the Dying Patient, supra note 153, at 163943. The Wilkinson court goes on to add that even a very small chance of death or serious disability may be relevant, and that the potential gain of a treatment should be weighed against its risks. In the legal context similar reasoning would compel greater care with high risk cases, especially death penalty or long term imprisonment situations. Although the courts have to this point been unwilling to admit that more competent or ethical counsel should be required in serious cases, judges usually act with special care in such trials. See B. Prettyman, JR., Death and the Supreme Court 305, 308-11 (1961). This natural human response, though difficult to implement in individual cases, is still an appropriate consideration in the inforined consent area. Surely, lawyers must take special care to inform their clients of the smallest risk when death is a possible outcome of a trial.

160. It could also be argued that medical decisions usually focus only on the doctor and the patient, while legal choices involve the lawyer, client, and an unpredictable adversary. The variety of familial, social, and einployment situations of patieuts and clients, however, makes it difficult to hazard a guess that the human side of a medical decision is any less complex than that of a crininal trial. 
cused. ${ }^{101}$ The disclosure duty rests on a theory of what a reasonable defendant, not a reasonable attorney, may seek to know. It also provides workable appellate standards by preserving the ability of the court to control unreasonable demands by defendants and protecting attorneys from making precise factual judgments in areas where exactitude is impossible.

\section{The Ethical Norms}

The organized Bar has accepted the traditional dominance of counsel in areas of trial tactics. Ethical rules describing an attorney's obligation to accept indigent criminal cases and the doininance of counsel at trial fail to provide any insight into the impact of Faretta.

As one might expect, generally accepted ethical norms require an attorney to make every reasonable effort to create and maintain a good relationship with his client. ${ }^{162}$ Such a relationship is the theoretical foundation relied upon by lawyers to obtain all facts necessary for the presentation of a defense. ${ }^{103}$ The norms do not, however, reveal any concern about the obstacles to a decent lawyer-client relationship introduced by Faretta. Although a lawyer is not under an "obligation to act as adviser or advocate for every person who may wish to become his client," ${ }^{164}$ he is limited to refusing assigned criminal cases only for "compelling reasons."165 In addition, an attorney may withdraw from a civil or criminal case in litigation only on the basis of "compelling circumstances"166 and, if required by local rule, with the permission of the court. Attorneys, therefore, may be compelled to accept criminal assignments and to remain involved even if the compelled attorneyclient relationship is flawed. In contrast, the Code requires retained counsel not to accept a case if the client is already represented by counsel, absent the agreement of the other attorney. ${ }^{167}$ The same concern

161. Compare the recent growth of law protecting patient control over medical decisions. See generally Katz, Who's Afraid of Informed Consent?, 4 J. PsYcH. \& L. 315 (1976); Note, Informed Consent and the Dying Patient, supra note 162; Cantor, A Patient's Decision to Decline Life Saving Medical Treatment: Bodily Integrity Versus Preservation of Life, 26 RuTGers L. Rev. 228 (1973).

162. The Defense Function, supra note 6, $\$ 3.1$; ABA Code, supra note 44, EC 7-8.

163. See The Defense Function, supra note 6, § 3.2; ABA Cope, supra note 44, EC 4-1. See also FrEeDMAN, supra note 148, at 1-8.

164. ABA CoDE, supra note 44, EC 2-26.

165. Id. EC 2-29; THE DEFENSE Function, supra note 44, § 1.5. The ABA Standards are based upon the felt need to widen the participation of attorneys in criminal defense work. Id. $\$ 1.5$, Comment. See ABA, Standards Relatino to Providino DEFENSE SERVICES \& 2.2 \& Comment (1972).

166. ABA CODE, supra note 44, EC 2-32.

167. Id. EC 2-30. 
should permit an attorney in a criminal case to refuse to continue when the defendant has a preference for another.

The ethical norms also strongly inply that mere tactical disagreements do not provide a basis for a withdrawal request. The Code generally provides that withdrawal is possible when the client's conteinplated conduct is illegal or inakes it unreasonably difficult for the attorney to carry out his employment effectively. ${ }^{168}$ Mere disagreement over tactics is unlikely to obstruct an attorney's effectiveness, since counsel may presently ignore a client's wishes and try the case his own way. In short, the interplay between the existing ethical and legal rules makes it highly unlikely that disagreement over trial preparation techniques or trial strategy will provide a basis for an attorney to be relieved or for a defendant to obtain a new lawyer. ${ }^{169}$ The ethical norms must

168. Id. DR 2-110(C) provides:

(C) Permissive withdrawal.

If $\mathrm{DR} 2-110$ (B) is not applicable, a lawyer may not request permission to withdraw in matters pending before a tribunal, and may not withdraw in other matters, unless such request or such withdrawal is because:

(1) His client:

(a) Insists upon presenting a claim or defense that is not warranted under existing law and cannot be supported by good faith argument for an extension, modification, or reversal of existing law.

(b) Personally seeks to pursue an illegal course of conduct.

(c) Insists that the lawyer pursue a course of conduct that is illegal or that is prohibited under the Disciplinary Rules.

(d) By other conduct renders it unreasonably difficult for the lawyer to carry out his employment effectively.

(e) Insists, in a matter not pending before a tribunal, that the lawyer engage in conduct that is contrary to the judgment and advice of the lawyer but not prohibited under the Disciplinary Rules.

(f) Deliberately disregards an agreement or obligation to the lawyer as to expenses or fees.

(2) His continued employment is likely to result in a violation of a Disciplinary Rule.

(3) His mability to work with co-counsel indicates that the best interests of the client likely will be served by withdrawal.

(4) His mental or physical condition renders it difficult for him to carry out the employment effectively. ment.

(5) His client knowingly and freely assents to termination of his employ-

(6) He believes in good faith, in a proceeding pending before a tribunal, that the tribunal will find the existence of other good cause for withdrawal.

169. At trial counsel must control most aspects of trial strategy, although consulting with his client on matters of importance. THE DEFENSE FUNCIION, supra note 6 , $\S \S 5.2(\mathrm{a})-(\mathrm{b})$. If a dispute over tactics erupts he must place the nature of the problem on the record without breaching the attorney-client privilege. Id. $\S 5.2(\mathrm{c})$. These obligations also present great difficulties. For example, why is it proper for a lawyer to continue in a case when his client disagrees with the manner in which the defense is to be presented? Does an attorney have an obligation to tell his client of the right to proceed pro se or to request new counsel? The usual feeling of counsel that pro se representation does not work well, together with the high ethical obligation to continue in assigned cases, implies that present ethical rules do not require such notice. On the other hand, the tensions in an attorney-client relationship may require an attor- 
be modified to reflect the possibility of mixed representation and to recognize counsel's information transfer duties after Faretta.

\section{Effective Counsel, Inarticulate Pro Se Defendants, and Faretta}

\section{Standards for Attorney Effectiveness}

Attorney skill in the courtroom, or in preparation for trial, has been the focus of most claims of ineffective assistance of counsel. ${ }^{170}$ When a defendant is deciding how to proceed in a mixed representation case, however, the central issue as to ineffective assistance will tend to be counsel's advice rather than his actions.

Advice problems may arise in any case in which a defendant has permitted counsel to perform some role. Even in pro se cases advisory counsel will often be appointed to provide information for an untutored defendant or continuity should an accused later waive his right to proceed pro se or lose his right to be present at trial. That such assistance comes by way of advice, rather than by direction, does not affect its importance. Absent a complete waiver of effective counsel, therefore, ineffective assistance rules should apply to measure the competency of counsel's performance, however slight his role.

Nor should the possible application of the ineffective assistance rules be ignored because harmless error rules may preclude relief in mixed representation trials to a greater degree than when counsel is in total charge. For example, suppose a defendant waived counsel for all purposes except cross-examination of government witnesses; suppose further not only that defendant's performance was harmful, but that counsel's cross-exannination was ineffective. The standard of review requires that the error resulting from ineffective counsel be harmless beyond a reasonable doubt in order to affirm the conviction. ${ }^{171}$ That defendant's participation was harmful, however, does not necessarily inean that counsel's ineffectiveness was harmless beyond a reasonable doubt. For effective counsel doctrines to sit comfortably with

ney to make efforts to resolve a dispute, even by taking steps he deems unwise, in order to preserve decorum before a jury.

170. See Annot., 26 A.L.R. FED. 218 (1976); Finer, supra note 35; Grano, supra note 8; Note, Effective Assistance of Counsel for the Indigent Defendant, supra note 35.

171. Chapman v. California, 386 U.S. 18, 24 (1967). The circuits differ as to who bears the burden of persuasion on the Chapman issue. Compare McQueen v. Swenson, 498 F.2d 207, 220 (8th Cir. 1974), and United States ex rel. Green v. Rundle, 434 F.2d 1112, 1115 (3d Cir. 1970) (burden on defendant), with United States v. DeCoster, 487 F.2d 1197, 1204 (D.C. Cir. 1973), and Coles v. Peyton, 389 F.2d 224, 226 (4th Cir. 1968) (burden on Government). 
Faretta, a careful inquiry is required into the harm caused by counsel in any area, no matter how small. ${ }^{172}$

This analysis is inconsistent with older ineffective assistance cases, in which a single due process standard was apphed to determine the need for reversal. Little concern was voiced over the question of harmless error as a separate issue because the concepts of error and harm were joined in the same standard: the court simply determined if the trial was a sham or a mockery of justice. ${ }^{173}$ Adherence to this standard is now eroding in favor of a rule requiring normally competent counsel ${ }^{174}$ nevertheless, in those circuits that retain it the joinder of harm and error makes analysis of mixed representation cases particularly difficult.

The sham standard is also flawed because it requires that an attorney be no more effective than a pro se defendant; more than a fourteenth amendment level of fair performance should be required of counsel in order to meet sixth amendment minima of effectiveness. Knowledge of the law, in addition to the ability to argue and communicate, is required of an attorney. A defendant who elects to use some or all of the abilities of counsel, presumably im part because he thinks he will be better tried, should be justified in his assumption. To continue to operate effective assistance of counsel rules on the minimal fairness protections of the due process clause is to ignore the higher level of competence expected of counsel by the coinmunity. The right to counsel in the sixth amendinent is largely based upon this community

172. The nature and timing of the postverdict inquiry to be made in ineffective assistance cases is in dispute. Some cases have virtually required counsel on appeal to institute proceedings under 28 U.S.C. $\$ 2255$ contemporaneously with the appeal so that the reviewing court on appeal can decide the sixth amendment claim on a complete record and thereby avoid unnecessary remands. In such cases the primary appeal is held in abeyance until the district judge has had a chance to review the sixth amendment claims. United States v. DeCoster, 487 F.2d 1197, 1204-05 (D.C. Cir. 1973); United States v. Tindle, 522 F.2d 689 (D.C. Cir. 1975). Since other courts have shown reluctance to remand cases arising on direct appeal to district courts for evidentiary hearings or even inquiries on affidavit (e.g., United States v. Huntley, 535 F.2d 1400, 1405 (5th Cir. 1976)), as a general proposition appellate counsel should seek relief under section 2255 as early as possible in the appeal process.

173. The old sham standard still governs in some circuits, United States v. Yanishefsky, 500 F.2d 1327, 1333 (2d Cir. 1974); Johnson v. United States, 485 F.2d 240, 241-42 (10th Cir. 1973); United States v. Benthiem, 456 F.2d 165, 167 (1st Cir. 1972); Krutchen v. Eyman, 406 F.2d 304, 312 (9th Cir. 1969).

174. A number of circuits have switched to a standard requiring that counsel be normally competent. United States $e x$ rel. Willians v. Twomey, 5.10 F.2d 634 (7th Cir.), cert. denied, 423 U.S. 827 (1975); Fitzgerald v. Estelle, 505 F.2d 1334, 1336 (5th Cir. 1974), cert. denied, 422 U.S. 1011 (1975); Beasley v. United States, 491 F.2d 687, 696 (6th Cir. 1974); Moore v. United States, 432 F.2d 730, 736 (3rd Cir. 1970). The Eighth Circuit also appears to be shifting its standard. McQueen v. Swenson, 498 F.2d 207, 214-15 (8th Cir. 1974). See also United States v. Ramirez, 535 F.2d 125, 129-30 (1st Cir. 1976). 
understanding. The modern effective assistance standard is more consistent with the defendant's expectations in a mixed representationor even an advisory counsel-context.

\section{Standards for Defendant Competence}

The recent developinent of a more modern effective counsel test, however, opens up new problems in the interrelationship between Faretta and the due process clause. Although special quality standards apply to the activity of counsel sanctioned by the sixth amendment, the general notion that trials may be so unfair that their verdicts are unacceptable applies regardless of the presence of counsel. A Faretta waiver of the effective assistance of counsel may not completely override the socially based notions of minimal justice contained in the due process clause. If it is apparent to the trial court that the defendant is likely to try some or all of his case in such a farcical manner that a reversal would be required under the fourteenth amendment, effective steps must be taken to protect the defendant.

Some examples of cases where overriding notions of justice would require imposition of effective counsel on defendants are pro se or mixed trials with defendants mentally incapable of deciding the counsel/pro se waiver issues; ${ }^{175}$ completely pro se trials where the defendant's behavior leads to his withdrawal from a courtroom or to his gagging, ${ }^{176}$ and pro se or mixed trials where a defendant, though capable of making a waiver decision, is so inarticulate that he is unable to communicate with the trier of fact or with witnesses. ${ }^{177}$ In each case the court would be obligated to declare a mistrial or appoint counsel to proceed with the trial. These results are analogous to those cases in which courts lave proceeded to try defendants incompetent to stand trial in

175. See Jackson v. Indiana, 406 U.S. 715 (1972); Massey v. Moore, 348 U.S. 105 (1954); United States ex rel. Martinez v. Thomas, 526 F.2d 750 (2d Cir. 1975); People v. Robles, 2 Cal. 3d 205, 466 P.2d 710, 85 Cal. Rptr. 166 (1970). In Gilmore v. Utah, 97 S. Ct. 436 (1976), a defendant sentenced to death under a statute of doubtful constitutionality moved the Supreme Court to terminate its stay of execution. The stay had been granted pursuant to a petition filed by the defendant's mother raising the constitutional questions and suggesting that her son was not competent to waive appeal. The stay was vacated and the competency resolved on the basis of the transcripts of the hearings at which Gilmore had refused to permit a state appeal to proceed and reports of state psychiatrists. No adversary hearing on the competency question was ever held, even after the condemned man attempted suicide. The heretofore clear due process holding of Pate v. Robinson, 383 U.S. 375 (1966), requiring sua sponte judicial inquiry when competence is called into question, was not cited or discussed by either the majority or the dissenters.

176. For fact situations that raise these issues see United States v. Jones, 514 F.2d 1331 (D.C. Cir. 1975); United States v. Theriault, 474 F.2d 359 (5th Cir. 1973).

177. Defendants proceeding pro se who are unable to raise bail also may present difficult due process problems. See Note, The Jailed Pro Se Defendant, supra note 110. 
order to avoid permanent incarceration without the benefit of a verdict. ${ }^{178}$

Extraordinarily inarticulate defendants provide the most difficult class of cases. Such a defendant-for example, a seriously retarded individual-though perfectly capable of understanding other people if they talk simply, may be incapable of carefully phrasing arguments or questions in anything approaching a logical pattern. He may understand that he has a right to counsel, and that counsel would provide valuable assistance, but still desire to try the case himself. In such circumstances the basic requirements of a traditional sixth amendinent waiver of effective counsel may be met. ${ }^{179}$

Faretta suggests that the court may not impose a sixth amendment requirement that the defendant be likely to perform well in order to proceed pro se. ${ }^{180}$ The likelihood that a defendant will be unable to perform, however, raises due process problems not dealt with by Faretta. The court should either find that sucls a defendant is incapable of making a waiver of counsel or permit lim to proceed pro se while intervening in the trial to promote some degree of fair opposition to the prosecutor. In either case, the court may justify its actions on the due process notion that some nimimal evenness in the operation of the adversary system is necessary. Just as due process issues like competency to stand trial are resolved by reviewing the ability of a defendant to understand the social force to be applied, so must the exercise of a Faretta waiver be related to the basic ability of the defendant to participate directly in the trial process.

\section{Comparing the Standards}

It night be thought contradictory to measure a pro se or mixed defendant's trial competence by a general due process fairness standard while measuring counsel's effectiveness by a higher standard emanating from the sixth amendinent. After all, the right to proceed pro se also

178. See Jackson v. Indiana, 406 U.S. 715 (1972); State v. Lang, 37 Ill. $2 \mathrm{~d} 75$, 224 N.E.2d 838 (1967). In Lang, a deaf mute was adjudged incompetent to stand trial and committed to an institution. A later state habeas petition led to a remand for a limited trial on those issues for which defendant's personal participation was not necessary. State ex rel. Myers v. Briggs, 46 Ill. 2d 281, 236 N.E.2d 109 (1970).

179. Faretta v. California, 422 U.S. 806, 835-36 (1975).

180. The Faretta court did note at one point that Faretta was "literate, competent, and understanding." Id. at 835 . Exactly what these words connote is not clear. It is possible that the example in the text of a retarded defendant may involve someone who is not "literate." The language appears to be inconsistent with the looser standard suggested earlier in the opinion: "[I]n order to represent himself, the defendant must knowingly and intelligently [waive his right to counsel]." Id. at 835 . One hopes that future judicial interpretations of the waiver standard will avoid potential conflict with due process requirements. 
arises independently under the sixth amendment. The sixth amendment rights to counsel and to proceed pro se, however, are independent of each other and different in content. The right to counsel has been construed as a right to effective assistance; the Faretta pro se right contains no guaranteed sixth amendment standard of competence. Waivers of one or the other right are, accordingly, soinewhat different in content. The notice and waiver structure described to this point encompasses this difference within it. The primary notion of waiver protected by Faretta is the right to err. The primary benefit waived is a competent spokesman. The primary function of the due process clause is to demand a minimally acceptable level of fairness in all proceedings. The suggested rules put into effect a system that both protects the general ability of defendants to nnake erroneous choices and prevents most reversals should the general expectations regarding the ability of pro se defendants prove valid. In essence the new effective assistance of counsel standards and the fourteenth amendment fairness standards reflect the likely minimal understandings of the parties prior to waiving either counsel or the right to proceed pro se.

\section{Judicial Efficiency Revisited}

Judicial application of the various rules proposed here presents some theoretical and practical difficulties. First, in what ways must courts differently treat pro se and represented defendants? Must a court, for example, ever make evidentiary objections on behalf of a pro se defendant? Second, under what circuinstances do efficiency needs justify restricting the ability of a defendant to proceed pro se or in a mixed fashion? At soine point the need to proceed speedily and with as little confusion as possible may justify restricting the whims of a fickle defendant.

\section{Judicial Obligations Under the Due Process Clause to Defendants Proceeding Pro Se or by Mixed Representation}

It is impossible to predict all of the problems that will confront the courts; nevertheless, several areas profitably may be discussed. First, accepting the notion that the due process fairness test to be applied in pro se and mixed cases relates to the ability of a defendant to coinmunicate to the triers of fact, the court has fewer obligations with regard to a defendant seeking only to influence counsel's activity than to a defendant seeking to participate directly in the trial. Similarly, mere coinpilation of numerous objections to questions or arguments of a pro se or mixed defendant would not be fatal to a conviction. Nor would a series of tactical blunders. Assuming that most legal argument occurs at the bench and that the prosecutor is not using the legal ineptness 
of the accused as a vehicle for arguing to the jury, no prejudice beyond that to be expected in a normal pro se case would arise. Traditional evidential impediments placed upon defendant's communication with the trier of fact need not be altered for constitutional reasons in most pro se or mixed trials.

Second, the court would have to pass certain legal information to a completely pro se accused. In some areas in which counsel has a burden to inform a defendant of rights and obligations, the duty to transfer information must be undertaken by the courts. Performing this duty cannot be expected to substitute for total or partial assignment of counsel, but it can be expected to raise the possible anarchy of a pro se adversary trial to minimal levels of organized contentiousness.

The fifth amendment rights to testify or to refuse to testify provide an intriguing example. ${ }^{181}$ Present law apparently does not require that the court inform represented defendants of their fifth amendment rights prior to making a decision on use of their own testimony. ${ }^{182}$ Prior to Faretta, however, the courts were generally treating pro se defendants differently, ${ }^{183}$ the rationale being that counsel is expected to discuss testimonial decisions with the defendant in the process of developing defense strategy. Putting aside for a moment the question of control over such decisions, the expectation of counsellor warnings was deemed an adequate substitute for judicial warnings in all but pro se cases.

A primitive judicial informed consent rule is operating. The decision whether a pro se defendant should personally communicate his story to the trier of fact is such an important aspect of the trial that judicial intervention is appropriate. Although a court may not be asked to perform exactly like counsel under the doctrine of informed consent,

181. Consider also the plea of guilty. A pro se plea should arguably be taken with much greater care than a plea of a represented defendant.

182. See note 142 supra. The few opinions are from state courts. See People v. Thomas, 43 Cal. App. 3d 862, 118 Cal. Rptr. 226 (1st Dist. 1974); People v. Sinith, 257 Mich. 319, 241 N.W. 186 (1932); People v. Hunley, 63 Mich. App. 97, 234 N.W.2d 169 (1975). Although there may not be an obligation to warn a defendant of his fifth amendment rights, it is good practice to do so.

183. Again, the cases holding that pro se defendants must be warned are state cases. People v. Glaser, 238 Cal. App. 2d 819, 48 Cal. Rptr. 427 (1st Dist. 1965); People v. Kramer, 227 Cal. App. 2d 199, 38 Cal. Rptr. 487 (2d Dist. 1964); State v. Lucas, 24 Conn. Supp. 353, 190 A.2d 511 (1963); People v. Morett, 272 App. Div. 96, 69 N.Y.S.2d 540 (1947). See also Annot., 79 A.L.R.2d 643 (1961). But see State v. Lashley, 21 N.C. App. 83, 203 S.E.2d 71 (1974). Cases dealing with a similar difference in treatment in other areas, such as jury waiver, did not surface in my research. That may be because jury waiver is a decision that must always be made affirmatively by someone, while warning on testimonial rights may be passively iguored. The result would be that records in pro se cases would routinely reflect questions on the jury issue; no appealable issue would result. 
it may properly be required to provide general information to pro se defendants of rights guaranteed them by the Constitution, when relevant to any particular trial, or of other rights likely to have serious repercussions in a proceeding. ${ }^{184}$

Third and finally, it could be argued that a court has the obligation to intervene whenever a pro se or mixed defendant is about to make a gaffe of extraordinary dimensions. Although Faretta does not require the courts to protect a pro se defendant from tactical errors, at some poimt a tactical error or a series of them may so diminish the likelihood of a fair trial that any further efforts on the defendant's part to communicate to the judge or jury would be in vain. For example, an unwitting production by a pro se defendant of testinony or exhibits that affirmatively deinonstrate guilt should be screened out, absent a clear desire on the part of the defendant to plead guilty. ${ }^{185}$

Imposing part of the defense function upon the court in pro se and mixed cases inevitably follows from balancing minimal due process notions with the sixth amendment right of defendants to represent themselves. The additional due process burdens imposed in pro se or mixed cases relate not so much to basic changes in constitutional law as to the change in the form of representation and the resulting diminution in sources of knowledge of basic rights available to pro se defendants.

\section{Practical Limits to Faretta}

Two sets of problem exist in the day-to-day operation of pro se and mixed representation cases. First, at what point during the trial process unust decisions about legal representation be made? May a defendant elect to proceed pro se or to cross-examine a certain witness at the last moment? Second, how precise inust the courts be in allocating trial functions im a mixed representation case? May the defendant demand that questions be framed in a particular way or that his counsel withdraw a question already asked?

As a general proposition, a knowing and intelligent waiver of a right does not preclude a change of mind. A waiver assunes "contract" status only when public policy requires that finality attach to the deci-

184. In addition, minimal knowledge of certain practical housekeeping niceties should be give to a pro se defendant. That is, the order of the pretrial and trial process, time limits, and the like should be described for reasons of efficiency, if not due process. A defendant should be informed of those periods of time when he will be permitted to communicate with judge and jury.

185. See Boykin v. Alabama, 395 U.S. 238 (1969); Brookhart v. Janis, 384 U.S. 1 (1966). It is quite likely that even when represented by counsel, the trial court has a duty to avoid practical guilty pleas without proper waivers. See id. 
sion. For example, if a defendant decides before the trial begins not to testify, and says so in a knowing and intelligent way to the trial court, no one would forbid his later taking the stand. Similarly, if a decision to proceed pro se is made at arraignment, there would be no policy reason for denying a request for counsel a week later. To the contrary, the general assumption that counsel performs better than a pro se defendant should compel courts to assign counsel to such a defendant. Although a very late request for counsel might be denied in rare instances for practical reasons, the "contract" status thus imposed upon the waiver of counsel arises for reasons not directly related to the initial waiver decision.

Before Faretta, courts generally did not permit defendants to proceed pro se at the last ininute. ${ }^{186}$ Completely dispensing with counsel at the last minute, however, or even in the middle of a trial does not present undue or unusual practical problems that warrant universally attaching contract status to an initial waiver of the pro se right. If counsel is fired because of sixth amendment ineffectiveness, appointment of new counsel ordmarily leads to a continuance to allow new counsel time to prepare. Similarly, a defendant who elects to proceed pro se after dismissing his ineffective counsel should also be provided time for preparation. Where the pro se choice arises for reasons other than counsel incompetence, however, the defendant has presumably waived his right to effective assistance and therefore the trial could usually proceed without delay.

The defendant who seeks to alter the scope of his waiver of counsel before or during trial presents an additional problem. The complexities of mixed representation probably require that once a trial begins a presumption of waiver stability arise; numerous bench conferences on control issues would be highly inefficient. Resolution of pretrial contract changes may easily be handled by delaying the sixth amendment waiver hearing until immediately before trial. ${ }^{187}$ The trial

186. See United States v. Dougherty, 473 F.2d 1113 (D.C. Cir. 1972); United States ex rel. Maldonado v. Denno, 348 F.2d 12 (2nd Cir. 1968).

187. Control issues may also arise in pretrial motion practice. A hearing similar to the one suggested in the text may be held at the beginning of any motion hearing in which both defendant and counsel participate. In addition, if motions are never made because the defendant refused to permit counsel to proceed, that decision should be placed on the record at the beginning of trial. These problems are not insignificant. Many defendants complain on appeal about the failure of counsel to make certain motions. They should be permitted both to require that certain motions be made and to forbid the making of others. The screening of "frivolous" motions is better performed by the courts than by counsel. If counsel refuses to proceed with a motion, the defendant should not be prohibited from filing a paper merely because he is represented by counsel.

Early hearings may also be required when evidence comes to light that the defendant is incompetent to make a sixth amendment waiver or to participate meaningfully 
court need not be aware of the exact nature of the mixed representation decision until trial is imminent. Defendant and counsel should be asked, before trial, to state on the record their understanding of the division of trial responsibilities. Although counsel has a continuing obligation to inform the court of disputes affecting case preparation, the vast majority of mixed representation cases could progress to trial without judicial intervention. Similar efficiency arguments would restrict the defendant's capacity to make significant midtrial alterations of the waivers. To avoid inappropriate imterruptions of trial, the trial court should be vested with discretion to prohibit alterations that exceed minor strategic changes.

Obviously, every trial event cannot be anticipated; nor can every question or objection be drafted before trial. Both the general unpredictability of the course of a trial and the criminal discovery rules necessarily limit the specificity of a pretrial mixed representation waiver hearing. Thus the particular witnesses to be called or to be crossexarmined and the particular exhibits to be used, for example, could not be specified at the hearing. The most that the pretrial waiver hearing can accomplish is delineation of general functions between counsel and defendant. It would, however, be quite possible to allocate who makes the decisions to call or cross-examine witnesses and to introduce certain exhibits.

The small residue of cases in which a surprise is not resolvable by reference to the general waivers may be simply handled. If the surprise is a result of significant governmental misbehavior, a continuance should normally result. In such cases the defense team should be permitted to regroup; contract status should not attach in such circumstances to the waivers. Finally, where the trial decision must be made instantaneously, the resolution should depend on a "residuary clause" in the general waivers. That is, all areas not dealt with in the general waivers should be allocated at the pre-trial hearing to either the defendant or counsel. ${ }^{188}$

\section{E. Collateral Attack and Faretta}

Faretta, like Henry v. Mississippi, ${ }^{180}$ is a federal review of a final state court judgment. As previously mentioned, the courts have incor-

in his trial. The competency questions, however, may certainly be resolved well before trial, as is typically done now, leaving the mixed representation decisions until later.

188. Imagime the "horror story" of the defendant who in the middle of trial gives counsel a note demanding that counsel ask the chicf government witness why he was "sure the defendant was the person who kicked the victim after he was already unconseious?" Assuming that cross-examination of government witnesses has been left with counsel, the note may be ignored. Obviously, all attorney-client disagreements may not be eliminated.

189. 379 U.S. 443 (1965). 
rectly looked to the deliberate bypass cases as a basis for deciding tactical control issues; collateral attack and proper allocation of authority over the defense at trial are distinctly separate inquiries. The issue now is whether the deliberate bypass doctrines are correct in light of Faretta.

Before Faretta the right to proceed pro se did not enjoy a clear constitutional base. ${ }^{100}$ Deliberate bypass doctrines had to be created to deal with the question of when collateral attack had been waived by prior actions of the defense. Consequently, courts perceived inost decisions made by either counsel or defendant as subjects for bypass analysis and accordingly restricted the availability of collateral review if any member of the defense team made a bypass that had a sound tactical basis. The issue was not just whether a waiver had occurred, but whether it was appropriate for federal courts to take another look at a case already litigated in state court.

Now that the pro se right has been clearly embedded in the Federal Constitution, it is appropriate to ask if Faretta dictates any changes in the deliberate bypass rules. That is, may a deliberate bypass occur as a result of a decision inade by a lawyer or a defendant who, under Faretta, did not have the right to make the decision? Though the apparent answer is no, the result is not obvious. The basic notion that stability of final state judgments is of some importance forces us to take another short trek into the deliberate bypass cases.

The old notion-embodied in Fay $v$. Noia ${ }^{191}$ and Henry $v$. Mississippi ${ }^{102}$ - that mere tactical decisions do not raise waiver issues of a constitutional dimension is false. Faretta transforms the issue into whether the decisional apparatus at trial should be treated differently in federal reviews of state convictions than in direct appeals. The Court in Stone $v$. Powell ${ }^{193}$ manifests the possibility that such a difference could arise. In Stone the Court refused to review the merits of a search claim previously litigated in state court because the additional deterrent value, if any, to be gained by extending the exclusionary rules beyond trial and appeal were outweighed by the cost to the truthfinding endeavors of the adversary system. ${ }^{194}$ Although sucl balancing of interests may be appropriate for fourth amendment purposes, there is no similar balance at work in Faretta. Even if the state court extends a "benefit" to a defendant by denying his motion for total or par-

190. See 28 U.S.C. $\$ 1654$ (1970); United States v. Dougherty, 473 F.2d 1113, 1123 (D.C. Cir. 1972).

191. 372 U.S. 391 (1963).

192. 379 U.S. 443 (1965).

193. 96 S. Ct. 3037 (1976).

194. Id. at 3049-52. 
tial pro se representation, Faretta requires a reversal because the harmless error rules are not applicable. In such circumstances the federal courts must be open for vindication of a federal claim that counsel overreached his right to control a defendant's trial. ${ }^{105}$

In the last analysis Faretta may significantly aid decisionmaking in habeas cases. Assuming that state courts are obligated to provide defendants with the option of proceeding pro se or in mixed fashion, the pretrial waiver hearing should provide an on-the-record decision by each defendant regarding the scope of control he desires to exercise over his own defense. A record of the sixth amendment waiver dialogue would significantly ease the judicial task of deciding if one party or the other had the authority to bypass a crucial federal right in a state court proceeding.

\section{CONCLUSION}

Faretta's impact is much more dramatic than the courts have yet recognized. It provides a constitutional basis for overruling the illogical and inconsistent doctrine that counsel must control trial tactics. This change presents serious practical difficulties. The problems can be largely overcome, however, by requiring pretrial waiver hearings at which a defendant specifies the extent to which he desires counsel and by redefining counsel's role in the attorney-client relationship. That a defendant proceeds without counsel should not deprive him of his right to due process; rather, the courts must intervene to ensure it.

With Faretta history has come full circle. Prior to Powell $v$. Alabama ${ }^{186}$ the use of counsel in criminal trials at the state and federal levels was appallingly low. ${ }^{197}$ The slow development of the constitutional right to counsel in criminal cases changed this picture dramatically. ${ }^{108}$ The passage of the Crimmal Justice Act of $1964^{100}$ and the implementation under the Act of the various district plans for provision

195. This proposition assumes that the issue was raised below and that no adequate state procedural ground exists for denying a defendant access to federal court. See Francis v. Henderson, 425 U.S. 536 (1976) (failure to make objection to composition of grand jury within period provided by state law constitutes waiver). It also assumes that a search question is not involved. Stone v. Powell, $96 \mathrm{~S}$. Ct. 3037 (1976). If counsel ineffectively advised a defendant on a search question, or ineffectively proceeded through a motion process, however, Stone would not prevent collateral review.

196. 287 U.S. 45 (1932).

197. For a review of the historical development of the right to counsel from the prerevolutionary era through 1955, see BeANEY, supra note 71. Data compiled as recently as 1962 still indicated that significant numbers of defendants were not assigned counsel. SilversteIn, supra note 3, at 89-104.

198. This constitutional development was certainly not preordained. The sixth amendment was probably drafted to protect only the right to retain counsel of choice. Sce BEANEY, supra note 71, at 14-26.

199. 18 U.S.C. § 3006A (Supp. 1976). 
of paid counsel in the federal courts ${ }^{200}$ have insured that counsel will routinely be provided in most federal criminal cases. ${ }^{201}$ In recent years judicial pronouncements on the right to counsel have often spoken of the careful inquiries necessary to insure the propriety of waivers of counsel. ${ }^{202}$ Although the development of the right to counsel has certainly been beneficial, difficulties with the developing rigidities of the right command attention. Even if the novelty of widespread access to assigned counsel justified certain rigidities, we have long since weathered the initial experimental storms. ${ }^{203}$

It has been written that

the more a man looks at a thing, the less he can see it, and the more a man learns a thing, the less he knows it. The Fabian argument of the expert, that the man who is trained should be the man who is trusted, would be absolutely unanswerable if it were really true that a man who studied a thing and practiced it every day went on seeing more and more of its significance. But he does not. 204

Faretta may help the legal profession learn that an expert attorney is of limited use to some and of no use to others.

200. Under the Criminal Justice Act of 1964 , each district was obligated to promulgate a plan for the implementation of the Act. Id. $\S 3006 \mathrm{~A}(\mathrm{a})$. For a survey of the plans see The Criminal Justice Act in the Federal District Courts, supra note 3.

201. In 1966 only 17 percent of federal criminal cases proceeded without counsel. Many of these were dismissal or nolle prosequi cases, or were immigration cases in the south or southwest. The Crmminal JUStice Act In the Federal District Courts, supra note 3, at 82-87.

202. See Ford v. Wainwright, 526 F.2d 919, 922 (5th Cir. 1976); United States ex rel. Martinez v. Thomas, 526 F.2d 750, 755 (2d Cir. 1975); United States v. Dujanovic, 486 F.2d 182, 185-86 (9th Cir. 1973); United States v. Plattner, 330 F.2d 271, 276 (2d Cir. 1964). In Plattner the Second Circuit recommended advising defendants of the right to proceed pro se. Nonetheless, the court also expressed its great concern that the pro se decision be made only after judicial advice to the defendant to accept counsel. Id.

203. In an area as complex as the criminal justice system, speedy alteration of historical patterns is likely to cause some disruption. Perhaps the single area where the disruption has been most pronounced is the juvenile courts. See generally W. Stapleton \& L. Teirtelbaum, In Defense of Youth (1972). The role of counsel in delinquency proceedings still is unsettled. See Kay \& Segal, The Role of the Attorney in Juvenile Court Proceedings: A Noh-Polar Approach, 61 Geo. L.J. 1401 (1973); Ferster, Courtless \& Snethen, The Juvenile Justice System: In Search of the Role of Counsel, 39 FordHAM L. REv. 375 (1971). The introduction of pro se representation and waiver of counsel problems into theljuvenile courts presents great difficulties. The propositions that counsel may never be waived by a juvenile and that counsel may make decisions for their young clients have more power in this context than in adult courts. See In re Appeal No. 544, 25 Md. App. 26, 332 A.2d 680 (1975); Kay \& Segal, supra at 1410-11. But see Comment, The Minor's Right to Medical Treatment: A Corollary of the Constitutional Right of Privacy, 48 S. CaL. L. Rev. 1417 (1975). Although this Article does not focus on juvenile problems, the discussion of pro se trials with inarticulate defendants is relevant to delinquency proceedings. See Section IV(C) supra.

204. G. Chesterton, Tremendous Trifles 57 (1955). 